Discussion Paper No. 16-089

\title{
The Impacts of the EU ETS on Efficiency - An Empirical Analyses for German Manufacturing Firms
}

Andreas Löschel, Benjamin Johannes Lutz, and Shunsuke Managi

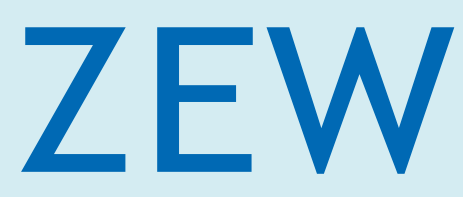

Zentrum für Europäische Wirtschaftsforschung $\mathrm{GmbH}$ Centre for European Economic Research 
Discussion Paper No. 16-089

\title{
The Impacts of the EU ETS on Efficiency - An Empirical Analyses for German Manufacturing Firms
}

\author{
Andreas Löschel, Benjamin Johannes Lutz, \\ and Shunsuke Managi
}

Download this ZEW Discussion Paper from our ftp server:

http://ftp.zew.de/pub/zew-docs/dp/dp16089.pdf

Die Discussion Papers dienen einer möglichst schnellen Verbreitung von neueren Forschungsarbeiten des ZEW. Die Beiträge liegen in alleiniger Verantwortung der Autoren und stellen nicht notwendigerweise die Meinung des ZEW dar.

Discussion Papers are intended to make results of ZEW research promptly available to other economists in order to encourage discussion and suggestions for revisions. The authors are solely responsible for the contents which do not necessarily represent the opinion of the ZEW. 


\title{
The Impacts of the EU ETS on Efficiency - An Empirical Analyses for German Manufacturing Firms
}

\author{
Andreas Löschel*,†, Benjamin Johannes Lutz† and Shunsuke Managi $\ddagger$ \\ *Westfälische Wilhelms-Universität, Münster, Germany \\ ${ }^{\dagger}$ Centre for European Economic Research, Mannheim, Germany \\ $\ddagger$ Kyushu University, Fukuoka, Japan
}

December 16, 2016

\begin{abstract}
We investigate the effect of the European Union Emissions Trading System (EU ETS) on the economic performance of manufacturing firms in Germany. Our difference-in-differences framework relies on several parametric conditioning strategies and nearest neighbor matching. As a measure of economic performance, we use the firm specific distance to the stochastic production frontier recovered from official German production census data. None of our identification strategies provide evidence for a statistically significant negative effect of emissions trading on economic performance. On the contrary, the results of the nearest neighbor matching suggest that the EU ETS rather had a positive impact on the economic performance of the regulated firms, especially during the first compliance period. A subsample analysis confirms that EU ETS increased the efficiency of treated firms in at least some two-digit industries.

Keywords: Control of Externalities, Emissions Trading, Economic Performance, Manufacturing, Difference-in-Differences, Nearest Neighbor Matching, Stochastic Production Frontier

JEL-Classification: Q52, D22, Q38, Q48
\end{abstract}

\footnotetext{
${ }^{*}$ Westfälische Wilhelms-Universität, Am Stadtgraben 9, 48143 Münster, Germany, Email: loeschel@uni-muenster.de.

${ }^{\dagger}$ Corresponding author. Centre for European Economic Research (ZEW), P.O. Box 1034 43, 68034 Mannheim, Germany, Email: benjaminjohanneslutz@gmail.com.

${ }^{\ddagger}$ Kyushu University, Fukuoka, Japan
} 


\section{Introduction}

The European Union (EU) aims at steering the European economy toward a competitive low-carbon pathway. Key to the EU's strategy is the EU Emissions Trading System (EU ETS) which was established in 2005 in order to cost-effectively curb greenhouse gas emissions from industrial installations. It is the world's largest international capand-trade system encompassing about 45 percent of the total European greenhouse gas emissions.

The EU ETS puts a price on greenhouse gas emissions from regulated installations and thus influences the production and investment decisions of regulated firms. There is concern that the EU ETS creates disadvantages for regulated firms exposed to competition from outside the EU. In particular, firms from the manufacturing sector that sell their goods and services on global markets might be vulnerable due to additional cost imposed through the EU ETS. In this paper, we study the causal effect of the EU ETS on the economic performance of regulated firms from the German manufacturing sector using official firm-level data.

For the evaluation of the EU ETS, the German manufacturing sector is a case of particular interest for two reasons. First, Germany is the largest economy and the largest emitter of greenhouse gases in the EU. In 2013, Germany emitted about 21 percent of the EU's total greenhouse gas emissions amounting to 976.3 million tonnes of $\mathrm{CO}_{2}$ equivalent (Eurostat, 2016). Second, German manufacturing is export oriented and therefore may be especially affected by a unilateral price on carbon emissions. In 2013, almost 50 percent of the produced goods and services were exported by the German manufacturing sector.(Destatis, 2015).

Despite the importance of the EU ETS, empirical evidence on its causal effects on the behavior of regulated firms is still scarce. Petrick and Wagner (2014) investigate the impact of the EU ETS on emissions, output, employment, and exports of manufacturing firms in Germany. They combine a difference-in-differences approach with semiparametric matching and weighted regressions in order to isolate the effect of the EU ETS. They show that the EU ETS reduced emissions of regulated firms by 20 percent during the years from 2007 to 2010. They do not find a significant negative effect of the EU ETS on employment, output, and exports. Following a similar approach, Wagner, Muûls, Martin, and Colmer (2014) show that the EU ETS reduced emissions of French manufacturing plants, by 15 to 20 percent on average between 2007 and 2010. They also find a significant decrease in employment in regulated plants of about 7 percent during the second compliance period of the EU ETS. Jaraite and Di Maria (2016) investigate the impact of the EU ETS on Lithuanian firms employing nearest-neighbor and kernel matching. They find that the EU ETS did not reduce $\mathrm{CO}_{2}$ emissions, but improved $\mathrm{CO}_{2}$ intensity. They do not find a significant effect on profits. However, regulated firms in Lithuania retired parts of their less efficient capital stock and made additional investments in the end of the second compliance period. Klemetsen, Rosendahl, and Jakobsen (2016) use a parametric difference-in-differences approach in order to isolate 
and quantify the effect of the EU ETS on emissions, emission intensity, value added, and labor productivitiy of Norwegian plants. They find that the EU ETS decreased emissions and at the same time increased value added and labor productivity during the second compliance period. Calel and Dechezleprêtre (2016) examine the effect of the EU ETS on technological change, in particular patenting. They combine patent and commercial firm-level data for Europe with data from the EU ETS. Using a matching approach, they find that the EU ETS increased the number of low-carbon patents among regulated firms by 10 percent between 2005 and 2010 while not crowding out patenting for other technologies. Lutz (2016) estimates a structural production function that allows for endogenous productivity and employs a parametric difference-in-differences approach in order to quantify the effect of the EU ETS on firm-level productivity. He shows that the EU ETS had a significant positive impact on productivity during the first compliance period. ${ }^{1}$

In this paper, we investigate the effect of the EU ETS on the economic performance of German manufacturing firms. We use a novel approach by combining causal analysis with the stochastic production frontier model. So far, the literature examines the impact of emissions trading on output and the use of inputs separately or assesses firm performance relative to the mean production function of an industry. In contrast, we use a measure of economic performance that relates input use and produced output and assesses performance relative to the most efficient firms of the industry: We estimate the stochastic production frontier model by Aigner, Lovell, and Schmidt (1977). The estimated frontier of the production set is determined by the efficient firms of the corresponding industry. The firm specific distance to the frontier is a comprehensive and comparable firm-level measure of economic performance. The stochastic production function model has been used in several studies that evaluate regulatory intervention, such as Knittel (2002), but has not been employed in the analysis of the impact of the EU ETS. Subsequently, we employ different identification strategies in order to identify and estimate the effect of the EU ETS on the distance between regulated firms and the production frontier. Our analysis is the first that isolates the causal effect of the EU ETS on a comprehensive measure of efficiency combining the difference-in-differences approach with the stochastic production frontier model. Furthermore, we add a novel view on the treatment heterogeneity of the effect of the EU ETS by conducting profound subsample analyses.

Following the studies depicted above, we exploit the installation-level inclusion criteria of the EU ETS that create variation in treatment. The EU ETS only covers emissions of installations with a capacity that exceeds thresholds determined by legislation. As a consequence, only firms operating large installations are covered by the EU ETS. The inclusion criteria allow the identification of the effects of the EU ETS based on an array of

\footnotetext{
${ }^{1}$ Our review of the recent literature focuses on studies that aim to investigate the causal effect of the EU ETS on regulated firms. For a comprehensive overview of the literature on the EU ETS, we refer to Martin, Muûls, and Wagner (2016)
} 
suitable identification strategies. We use a difference-in-difference framework combined with an array of parametric conditioning strategies and nearest neighbor matching in order to identify and estimate the effect of the EU ETS on the economic performance of the regulated firms.

We use official firm-level data that is collected by the German statistical offices. It comprises general characteristics, such as revenues, value added, employment, and investment and is particularly detailed with regard to fuel and electricity use. The data serves as a basis for many official German governmental statistics and includes all manufacturing firms with more than 20 employees. Our panel covers two pretreatment years (2003-2004) as well as the first (2005-2007) and the second compliance period (2008-2012) of the EU ETS.

Applying a difference-in-differences approach combined with parametric conditioning strategies to the full census, we do not find a significant effect of the EU ETS on the performance of regulated firms. In order to investigate potential heterogeneous treatment effects across industries, we conduct a subsample analysis following the same design. We estimate the treatment effect on the two-digit level for the industries manufacture of food products (10), manufacture of paper and paper products (17), manufacture of chemicals and chemical products (20), and manufacture non-metallic mineral products (23). We find that some industries remain unaffected, while others display economically and statistically significant impact of the EU ETS on efficiency. In these industries, the EU ETS had a significant positive impact on the efficiency of the regulated firms. In other words, on average the EU ETS decreased the firm specific distance to the production frontier when the firm was regulated.

The application of an alternative identification strategy further strengthens our findings. We employ nearest neighbor matching to account for observable differences between treated and untreated firms. The nearest neighbor matching allows us to relax the parametric assumptions of the standard difference-and-differences approach that are applied to the treatment and outcome model. While the results of the parametric difference-indifferences approach do not show significant effects based on the full sample, the results of nearest neighbor matching indicate a statistically and economically significant positive effect of the EU ETS on the efficiency of the regulated firms during the first compliance period.

The remainder of our paper is organized as follows. In Section 2, we describe the regulatory framework of the EU ETS. Section 3 outlines the identification strategy employed to isolate the effect of the EU ETS on the firm specific distance to the production frontier. Section 4 describes the German production census and additional data sources. Section 5 reports the results and Section 6 concludes. 


\section{The EU ETS}

The EU ETS is the largest multinational cap-and-trade system covering around 45 percent of the EU's greenhouse gas emissions. As core instrument of EU climate policy, it was enacted by Directive 2003/87/EC in October 2003 and finally implemented in January 2005 (European Parliament and Council, 2003). The EU ETS regulates the emissions of more than 11,000 energy-intensive industrial installations across the 31 countries of the European Economic Area (EEA) ${ }^{2}$.

The EU ETS is organized in temporally separated compliance periods. Phase I (2005 - 2007) is marked as pilot or introductory phase. Since only few member states had experiences with emissions trading, the European Commission accorded regulators and firms time to adapt to this new instrument. ${ }^{3}$ Phase II (2008 - 2012) of the EU ETS corresponds to the commitment period of the Kyoto Protocol (European Parliament and Council, 2004). The following Phases III (2013 - 2020) and IV (2021 - 2030) implement the emission targets in the 2020 Climate and Energy Package and the 2030 Climate and Energy Framework, respectively (European Parliament and Council, 2009).

Accordingly, the cap of the EU ETS is annually lowered by 1.74 percent during Phase III. This corresponds to a reduction of emissions by 21 percent relative to 2005 in 2020 . From 2021 onwards, the cap should be decreased by 2.2 percent annually (European Council, 2014). The emission rights that are traded in the framework of the EU ETS are referred to as European Union Allowances (EUAs). One EUA corresponds to one metric tonne of $\mathrm{CO}_{2}$ equivalent. Each year, firms that are regulated by the EU ETS must surrender EUAs according to their verified emissions.

During the first two compliance periods, the main mode of allocation was grandfathering. The allocation of allowances was governed decentralized at the member state level by the National Allocation Plans. Furthermore, member states were responsible for setting up national registries to record the issuance, transfer, and surrender of EUAs. The European Commission supervised the national emission registries by maintaining the Community Independent Transaction Log (CITL). Emissions of regulated installations are monitored and reported annually by the firm and verified by independent auditors. The penalty for non-compliance with the EU ETS was EUR 40 per EUA in Phase I and EUR 100 in Phase II. From the beginning of Phase III, the allowance allocation was centralized and the main mode of allocation started to gradually shift from grandfathering to auctioning.

Our analysis focuses on the first two compliance periods of the EU ETS. Phase I was completely decoupled from Phase II. Banking and borrowing was allowed across years within each compliance period, but not between Phase I and II. As a consequence, a tremendous over-allocation of free EUAs during Phase I led to a decline in EUA prices from above EUR 25 to zero in 2007. In Phase II, the EU ETS also suffered from massive

\footnotetext{
${ }^{2}$ The EEA includes the 28 EU member states as well as in Iceland, Liechtenstein, and Norway.

${ }^{3}$ Only UK and Denmark had experiences with national greenhouse gas emissions trading systems when the EU ETS was established in 2005.
} 
over-allocation. Due to the decline in economic activity and thus $\mathrm{CO}_{2}$ emissions in the wake of the economic crisis, the unadjusted supply of free allowances led to an oversupply of allowances. This development was enhanced by the heavy use of certificates issued by CDM and JI projects. In contrast to Phase I, however, it was possible to bank EUAs for future use in the following compliance periods. As a result of these developments, the EUA price decreased from more than EUR 25 at the beginning of Phase II to less than EUR 10 in the second half of Phase II. ${ }^{4}$

In the manufacturing sector, combustion installations for the generation of electric power and heat with a rated thermal input in excess of 20 megawatts as well as energy intensive production processes are regulated. These processes include oil refining, the production and processing of ferrous metals, the manufacture of cement, the manufacture of lime, ceramics including bricks, glass, and the production and processing of pulp and paper are regulated. The EU ETS only regulates large installations with capacities in excess of process-specific thresholds determined by regulation. ${ }^{5}$ Table 1 shows the total number of firms and the number of regulated firms in our data set of the German manufacturing sector across two-digit industries classified by the NACE code. The regulated processes are concentrated in a few energy intensive industries.

There exist firms both regulated and unregulated in the same industries. The inclusion criteria therefore create variation in the treatment status and enable us to identify the causal effects of the EU ETS. We will take into account the structural differences across regulated and unregulated firms by using different parametric and nonparametric strategies explained in the following section.

\footnotetext{
${ }^{4}$ More details on the EUA price development can be found in Appendix B.

${ }^{5}$ More details on the inclusion criteria of the EU ETS can be found in European Parliament and Council, 2003).
} 
Table 1: Number of observations by industry: total and regulated firms

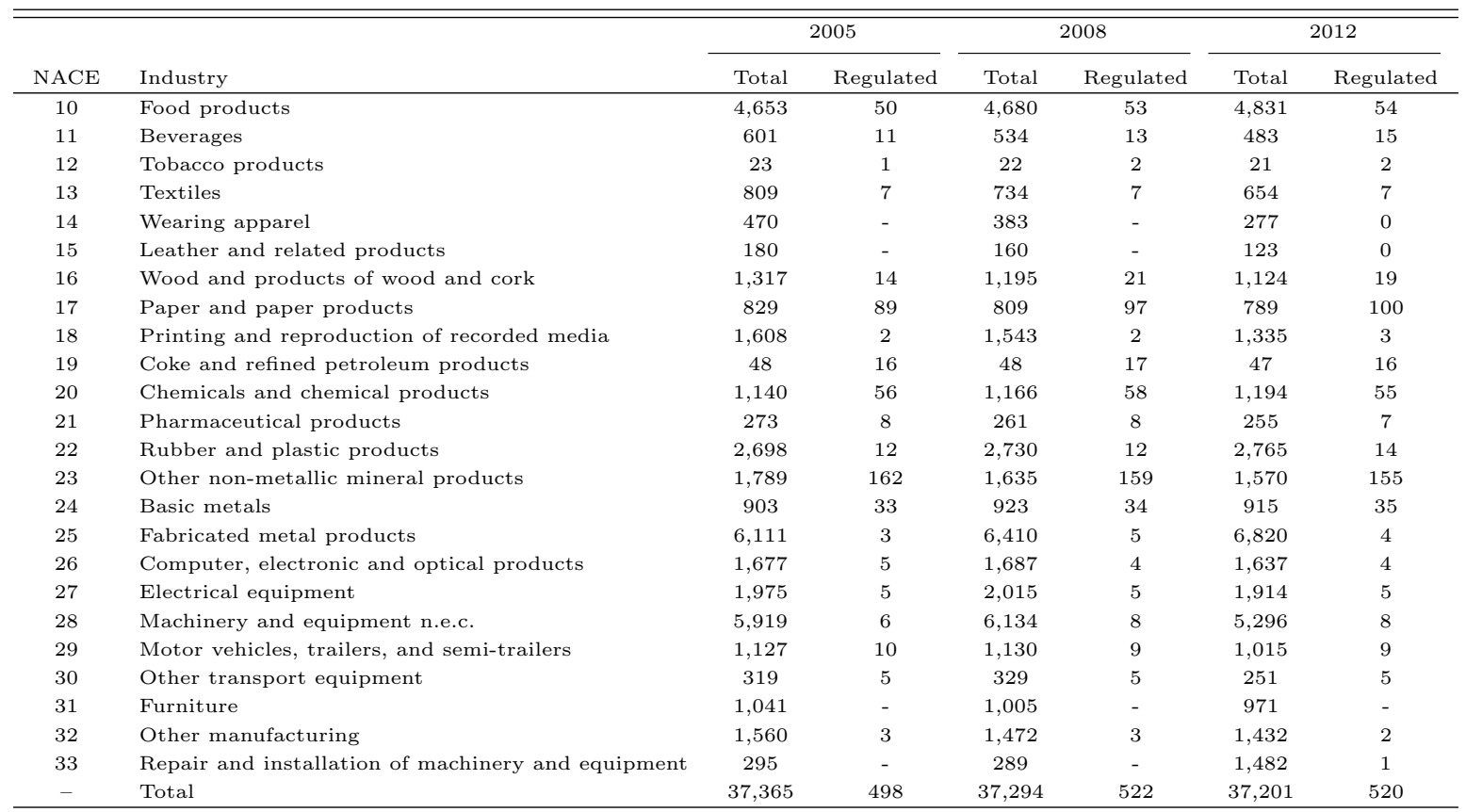

Notes: Number of firms for the first year of Phase I of the EU ETS (2005), the first year of Phase II (2008) and the last year of Phase II (2012) that is also the last year we observe. Source: Research Data Centres of the Statistical Offices Germany (2014): Official Firm Data for Germany (AFiD) - AFiD-Panel Industrial Units and AFiD-Module Use of Energy, own calculations.

\section{Empirical strategy}

In this study, we use the model by Aigner, Lovell, and Schmidt (1977) and Meeusen and van den Broeck (1977) in order to estimate the stochastic production frontier. In contrast to the estimation of average production functions, the stochastic frontier analysis enables the estimation of the frontier of the production set. This function expresses the maximum amount of output that can be produced from a given set of inputs with a fixed technology. We use the firm specific distance to the frontier as measure of economic performance.

According to Aigner, Lovell, and Schmidt (1977), the production process is influenced by a composite error term that consists of two economically distinguishable unknown random variables. The first component of the error term characterizes deviations from the optimal production frontier that result from decisions by the firm, e.g. mismanagement or suboptimal use of inputs. This random variable can be interpreted as a non-positive indicator for inefficiency. The second component of the error term captures noise and takes into account random factors that are not controlled by the firm, such as weather or unpredicted changes in the performance of machinery and employees, for example due to malfunction or illness. We follow Aigner, Lovell, and Schmidt (1977) and estimate the stochastic production frontier

$$
\ln y_{i t}=\ln f\left(\mathbf{x}_{i t}\right)+\nu_{i t}+u_{i t},
$$

where $y_{i t}$ denotes the output of firm $i$ at year $t, f\left(\mathbf{x}_{i t}\right)$ is the deterministic production 
frontier, $\mathbf{x}_{i t}$ is a vector of inputs, $\nu_{i t}$ is a nonpositive random variable depicting inefficiency, and $u_{i t}$ is a independently and identically distributed error term with zero mean and constant variance. We assume the deterministic frontier $f\left(\mathbf{x}_{i t}\right)$ to take the form of a Cobb-Douglas function. The vector of inputs $\mathbf{x}_{i t}$ includes capital stock, labor and energy use. We assume the efficiency component $\nu_{i t}$ to be drawn from a truncated normal distribution $\mathrm{N}^{+}\left(\mu_{\nu}, \sigma_{\nu}^{2}\right)$ and the noise component $u_{i t}$ to be drawn from a symmetric normal distribution $\mathrm{N}\left(0, \sigma_{u}^{2}\right)$. We implement the model using maximum likelihood estimation. In order to account for industry specific technologies, we estimate the stochastic frontier model for each two-digit industry within the German manufacturing sector. The distance to the frontier refers to a joint frontier for the years from 2003 to 2012. The estimated distance to the frontier also captures dynamic factors that might drive firm's efficiency, such as technological change. Our identification strategy will take these characteristics of the distance to the production frontier into account.

\subsection{Identifying the effect of the EU ETS}

The EU ETS only covers $\mathrm{CO}_{2}$ emissions of installations with a capacity that exceeds thresholds determined by the regulatory authorities. ${ }^{6}$ We exploit this variation created by the inclusion criteria of the EU ETS in order to isolate the effect of the EU ETS on the distance between regulated firms and the efficient production frontier. We follow the literature on program evaluation and employ the potential outcome framework introduced by Rubin $(1974,1977) .{ }^{7}$ We differentiate between treatment and control group depending on whether a firm has to comply with the regulation by the EU ETS or not. Let the binary variable $E T S_{i} \in\{0,1\}$ be an indicator that describes the treatment status of firm $i$. Let $E T S_{i}$ be equal 1 if the firm operates installations that are regulated by the EU ETS and 0 if the firm is not required to participate in the EU ETS. Accordingly, we describe the potential outcomes by $Y_{i}(1)$ and $Y_{i}(0)$ for treatment and control group, respectively. Our aim is to estimate the sample average treatment effect on the treated (SATT):

$$
\tau=E\left[Y_{i t}(1)-Y_{i t}(0) \mid E T S_{i}=1\right],
$$

where $\tau$ is the average effect of the EU ETS on the distance between regulated firms and the efficient production frontier after the implementation of the EU ETS. While we are able to observe $Y_{i t}(1)$ for regulated firms, the outcome $Y_{i t}(0)$ is not realized in the case of regulated firms. Therefore, we will use information on the outcome $Y_{i t}(0)$ collected from the firms that belong to the control group in order to form an adequate counterfactual. The comparison of the two groups will only lead to robust results, if factors that are correlated with efficiency dynamics do not differ across treatment and control group. In the following sections, we will present strategies that take this potential source of bias

\footnotetext{
${ }^{6}$ See Section 2 for details.

${ }^{7}$ The potential outcome framework has become a common way to describe an identification strategy in policy evaluation literature. Also, studies investigating the effects of emission trading schemes frequently rely on the potential outcome framework, see for instance Fowlie, Holland, and Mansur (2012).
} 
into account.

\subsection{Difference-in-differences}

We start from a baseline difference-in-differences specification. In order to control for observed and constant unobserved confounding factors, we gradually enhance the model by including explanatory variables and firm-level fixed effects into the estimation equation. ${ }^{8}$

The key identifying assumption of our baseline difference-in-differences specification is, that the efficiency trends would be the same in the treatment and control group in the absence of the EU ETS. We will investigate the validity of the common trend assumption by analyzing pretreatment developments of efficiency across treatment and control group in Section 5.2. In addtion, we assume that the EU ETS only has an effect on regulated entities. This assumption is often referred to as stable unit treatment value assumption (SUTVA) and basically excludes general equilibrium effects and spillover effects.

Our baseline specification of the difference-in-differences model takes the form

$$
\ln Y_{i t}=\beta_{0}+\beta_{1} E T S_{i}+\tau E T S_{i} \times \mathrm{I}(t \geq 2005)+\varphi_{t}+\gamma_{s}+\eta_{s t}+\varepsilon_{i t},
$$

where $\mathrm{Y}_{i t}$ denotes the outcome variable distance to the stochastic production frontier of firm $i$ in year $t$, as described above. ETS $S_{i}$ is a dummy that indicates if the firm must comply with the EU ETS, $\mathrm{I}(t \geq 2005)$ is a dummy that indicates if the year $t$ lies in the treatment period, $\varphi_{t}$ is a year fixed effect, $\gamma_{s}$ is an industry fixed effect, $\eta_{s t}$ is the interaction term of year and industry fixed effect, and $\varepsilon_{i t}$ is a zero mean error term. Our interest lies in the coefficient $\tau$ that measures the average treatment effect of the EU ETS on the distance between regulated firms and the efficient production frontier.

For our baseline specification, we assume that the counterfactual distance to the frontier is equally distributed across treatment and control group conditional on group, two-digit industry, and year fixed effects and a full set of interaction terms. We relax this conditional unconfoundedness assumption by controlling for additional confounding factors that might be correlated with both the treatment and the distance to the frontier. Since the compliance with the EU ETS depends on the capacity of the installation, especially factors related to the scale of the production and the size of the firm might impede the estimation of the average treatment effect. Regrettably, we do not observe the capacity, but we include among other controls the value of the physical capital stock in order to take scale effects into account. We consider the following specification of the difference-in-differences model that includes additional explanatory variables:

$$
\ln Y_{i t}=\beta_{0}+\beta_{1} E T S_{i}+\tau E T S_{i} \times \mathrm{I}(t \geq 2005)+\mathbf{z}_{i t} \Psi+\varphi_{t}+\gamma_{s}+\eta_{s t}+\varepsilon_{i t},
$$

\footnotetext{
${ }^{8}$ The procedure to start from a baseline difference-in-differences approach and then to enhance it gradually is quite common in the program evaluation literature. Gray, Shadbegian, Wang, and Meral (2014) employ a similar approach to investigate the effects of environmental regulation on employment of the U.S. paper industry. Lutz (2016) and Klemetsen, Rosendahl, and Jakobsen (2016) choose this strategy in order to identify the effect of the EU ETS on German firms and Norwegian plants, respectively.
} 
where $\mathbf{z}_{i t}$ denotes a vector of firm characteristics and $\Psi$ is the vector with the corresponding coefficients. We now further relax the assumption of conditional unconfoundedness by allowing for unobserved constant factors. In particular, we estimate a specification of the difference-in-differences model that includes a firm-level fixed effect:

$$
\ln Y_{i t}=\beta_{1} E T S_{i}+\tau E T S_{i} \times \mathrm{I}(t \geq 2005)+\mathbf{z}_{i t} \Psi+\alpha_{i}+\varphi_{t}+\eta_{s t}+\varepsilon_{i t},
$$

where $\alpha_{i}$ denotes the firm-level fixed effect that captures constant characteristics of the firm, such as average capacity and location. ${ }^{9}$

\subsection{Nearest neighbor matching}

In addition to the parametric difference-in-differences model, we estimate a model based on nearest neighbor matching in order to relax the assumptions on the functional form of the treatment and outcome model. In the program evaluation literature on emission trading schemes, matching has become quite popular in recent years. Fowlie, Holland, and Mansur (2012) employ a nonparametric matching strategy in order to investigate the effectivity of the Californian RECLAIM program. Petrick and Wagner (2014), Wagner, Muuls, Martin, and Colmer(2014), Jaraitè and Di Maria (2016), and Calel and Dechezlepretre (2016) implement different matching approaches in order to investigate the impact of the EU ETS on emissions, competitiveness, and R\&D activities of regulated firms. Our matching approach is closely related to the one employed by Fowlie, Holland, and Mansur (2012), since we use nonparametric nearest neighbor matching in order to form an adequate control group. The matching approach enables us to relax some of the assumptions we have to make in the framework of the difference-in-differences approach described above. We do not pose any parametric assumptions on the relationship between the distance to the frontier and the explanatory variables $\mathbf{z}_{i t}$. However, we still rely on the conditional unconfoundedness and SUTVA. For the matching approach, the common support assumption is of particular importance, i.e. we assume the conditional probability to be treated is larger than 0 and smaller than 1: $0<P\left[E T S_{i}=1 \mid X\right]<1$. In accordance with Heckman, Ichimura, and Todd (1997) and Heckman, Ichimura, Smith, and Todd (1998), we estimate the average treatment effect using the following differencein-differences matching estimator

$$
\hat{\tau}=\frac{1}{N} \sum_{j \in I_{1}}\left\{\left(Y_{j t^{\prime}}(1)-Y_{j t^{0}}(0)\right)-\sum_{k \in I_{0}} w_{j k}\left(Y_{k t^{\prime}}(0)-Y_{k t^{0}}(0)\right)\right\},
$$

where $I_{1}$ denotes the set of regulated firms, $I_{0}$ denotes the set of the unregulated firms, $N$ is the number of firms in the treatment group. The regulated firms are indexed by $j$, whereas the unregulated firms are indexed by $k$. Let $w_{j k}$ denote the weight placed on firm $k$ when constructing the counterfactual estimated for the treated firms. We employ matching on firm characteristics within two-digit industries in order to form an adequate control group.

\footnotetext{
${ }^{9}$ Industry fixed effects drop out, since these are constant over time.
} 


\section{Data}

We employ official firm-level data collected by the German Federal Statistical Office and the Statistical Offices of the German Federal States. The Official Firm Data for Germany (Amtliche Firmendaten für Deutschland - AFiD) is a highly reliable data source that forms the basis of many official German governmental statistics. The participation in the underlying production census is mandatory by law and the results of the conducted surveys are validated by the statistical offices.

We have remote access to annual data from 2003 to $2012 .{ }^{10}$ AFiD is of modular nature, i.e. the statistical offices conduct annual surveys on different topics and combine the collected data to thematic modules. We use the longitudinal census database AFiDPanel Industrial Units that contains annual data from the Monthly Report on Plant Operation, the Census on Production, and the Census on Investment. This module contains detailed information on inputs and outputs that describe the production process. In addition, we use the AFiD-Module Use of Energy. It is a longitudinal census that combines results from the Census on Energy Use and the Monthly Report on Plant Operation. It includes comprehensive data on electricity and fuel purchase, sale, and use. The AFiD-Panel Industrial Units and the AFiD-Module Use of Energy have the same group of respondents: All German plants that are active in manufacturing and belong to firms that employ more than 20 persons must participate in the underlying surveys. We aggregate plant level data to the firm level using the firm affiliation provided by the AFiD-Panel Industrial Units. The firms are classified according to ISIC rev. $4{ }^{11}$

As output variable for our stochastic production frontier model, we employ the value of production in the corresponding year denoted in EUR. The output variable has been deflated using two-digit industry specific price indices. The capital stock is computed by applying the perpetual inventory method to the investment data contained in the AFiDPanel Industrial Units and is denoted in EUR. A detailed description of the methodology and its application to AFiD data can be found in Lutz (2016). The number of employees in the firm indicates the use of labor. The aggregated energy use is computed based on the electricity and fuel use information contained in the AFiD-Module Use of Energy and is measured in MWh. We compute the $\mathrm{CO}_{2}$ emissions from the fuel use and the net use of electricity contained in the AFiD-Module Use of Energy exploiting data on $\mathrm{CO}_{2}$ content in fuels and electricity from the German statistical offices and the Federal Environmental Agency. The computation of the emissions as well as the emission coefficients

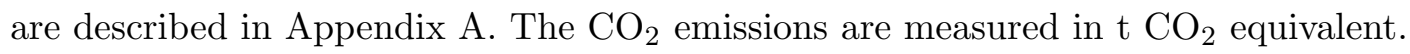

In order to identify firms that are regulated by the EU ETS, we match the production census with data of the European Union Transaction Log (EUTL) from the years 2005 to 2012 using the commercial register number and the VAT number. During the

\footnotetext{
${ }^{10}$ We also have access to data for the years from 1995 to 2002 . However, the statistical offices changed the survey gathering the information on energy use in 2003 making it difficult to include the data before 2003 into our investigation.

${ }^{11}$ In Appendix A, we present additional information on the industry classification.
} 
period from 2005 to 2012, a total of 1051 German firms was regulated by the EU ETS. We are able to match 77 percent (813 firms) of the firms in the EUTL with AFiD data. The remaining 238 firms mainly belong to the energy sector, the public sector (hospitals and universities), or the service sector (e.g. airports and exhibition centers) and thus could not be matched with a production census that only contains information of manufacturing firms.

Table 2 shows descriptive statistics of the variables used in the study for the entire manufacturing sector. The output as well as the use of inputs increase over time. However, the economic crisis is reflected in the descriptive statistics especially for the year 2009 when in particular output, emissions, and energy use declined. The number of employees was not much affected e.g. due to the support programs and the strict labor market regulation. The capital stock also remained quite stable, however, it slightly decreased in the aftermath of the crisis due to low investments during the crisis. The number of observations vary across variables within years, since the information is collected through different surveys as explained above. ${ }^{12}$

Table 2: Descriptive statistics German production census

\begin{tabular}{|c|c|c|c|c|c|c|c|c|}
\hline & Mean & SD & Skewness & Kurtosis & $\mathrm{P} 10$ & P50 & P90 & $\mathrm{N}$ \\
\hline \multicolumn{9}{|l|}{2003} \\
\hline Output (in 1,000 EUR) & $28,699.22$ & $360,632.64$ & 81.42 & $8,262.81$ & $1,324.71$ & $5,276.71$ & $42,903.50$ & 37,888 \\
\hline Emissions (in t $\mathrm{CO} 2$ ) & $7,343.68$ & $119,327.97$ & 49.20 & $2,996.19$ & 64.39 & 374.07 & $5,236.04$ & 36,985 \\
\hline Capitalstock (in 1,000 EUR) & $11,322.21$ & $120,382.53$ & 53.92 & $3,524.23$ & 256.28 & $1,838.52$ & $16,220.64$ & 37,099 \\
\hline Number of employees & 153.06 & $1,292.85$ & 71.69 & $6,278.85$ & 22.58 & 50.00 & 254.00 & 38,319 \\
\hline Energy use (in MWh) & $21,418.67$ & $376,270.67$ & 49.81 & $2,991.01$ & 161.79 & 911.97 & $12,979.47$ & 36,949 \\
\hline \multicolumn{9}{|l|}{2006} \\
\hline Output (in 1,000 EUR) & $33,903.31$ & $417,111.75$ & 77.80 & $7,509.40$ & $1,483.30$ & $6,201.49$ & $49,867.54$ & 36,162 \\
\hline Emissions (in t $\mathrm{CO} 2$ ) & $8,978.83$ & $193,026.98$ & 69.25 & $6,186.59$ & 72.56 & 412.27 & $5,742.81$ & 35,654 \\
\hline Capitalstock (in 1,000 EUR) & $11,097.78$ & $121,072.64$ & 60.25 & $4,516.43$ & 248.68 & $1,774.37$ & $15,880.93$ & 36,073 \\
\hline Number of employees & 154.01 & $1,313.92$ & 73.58 & $6,446.77$ & 23.90 & 52.92 & 254.75 & 36,632 \\
\hline Energy use (in MWh) & $27,200.64$ & $618,927.15$ & 64.61 & $5,055.30$ & 186.25 & 994.59 & $14,296.39$ & 35,631 \\
\hline \multicolumn{9}{|l|}{2009} \\
\hline Output (in 1,000 EUR) & $29,257.35$ & $345,810.11$ & 77.27 & $7,309.36$ & $1,295.66$ & $5,346.61$ & $44,534.20$ & 36,703 \\
\hline Emissions (in t $\mathrm{CO} 2$ ) & $7,989.21$ & $179,143.00$ & 69.44 & $5,857.38$ & 66.90 & 362.56 & $5,017.29$ & 36,100 \\
\hline Capitalstock (in 1,000 EUR) & $11,148.64$ & $119,355.75$ & 60.18 & $4,565.63$ & 234.60 & $1,785.08$ & $16,464.80$ & 36,335 \\
\hline Number of employees & 152.47 & $1,219.86$ & 70.98 & $6,127.83$ & 24.00 & 53.00 & 254.50 & 36,982 \\
\hline Energy use (in MWh) & $26,043.38$ & $627,994.42$ & 70.33 & $5,934.58$ & 179.39 & 920.20 & $13,337.29$ & 36,074 \\
\hline \multicolumn{9}{|l|}{2012} \\
\hline Output (in 1,000 EUR) & $35,194.48$ & $514,872.08$ & 89.04 & $9,350.33$ & $1,431.54$ & $6,184.66$ & $51,415.54$ & 36,882 \\
\hline Emissions (in t $\mathrm{CO} 2$ ) & $9,012.12$ & $211,455.53$ & 71.14 & $6,276.90$ & 68.58 & 385.09 & $5,489.93$ & 36,435 \\
\hline Capitalstock (in 1,000 EUR) & $10,641.92$ & $122,387.63$ & 58.11 & $4,256.77$ & 240.51 & $1,611.20$ & $14,924.90$ & 36,380 \\
\hline Number of employees & 157.09 & $1,300.76$ & 69.85 & $5,901.93$ & 25.00 & 54.83 & 260.33 & 37,130 \\
\hline Energy use (in MWh) & $29,383.97$ & $745,139.74$ & 73.12 & $6,467.69$ & 183.05 & 951.67 & $14,134.01$ & 36,421 \\
\hline
\end{tabular}

Notes: Output (production value) and capital stock are denoted in 1,000 EUR. Energy use is denoted in MWh and $\mathrm{CO}_{2}$ emissions in $\mathrm{C} \mathrm{CO}_{2}$ equivalent. Source: Research Data Centres of the Statistical Offices Germany (2014): Official Firm Data for Germany (AFiD) - AFiD-Panel Industrial Units and AFiD-Module Use of Energy, own calculations.

Figure 1 shows the development of the variables over time across two-digit industries within the manufacturing sector. We plot the development of the indexed median (base year 2003) of each variable for the industries manufacture of food products (10), manufacture of paper and paper products (17), manufacture of chemicals and chemical

\footnotetext{
${ }^{12}$ The surveys are not conducted at the exact same date and thus the number of firms might vary to a minor degree.
} 
products (20), and manufacture of non-metallic mineral products (23), such as glass and cement. ${ }^{13}$ These four sectors cover more than half of the German manufacturing firms regulated by the EU ETS. While the development of output as well as input use in the food industry was barely affected by the economic crisis, the other graphs for these industries show a strong impact on output, emissions, and energy use in 2009. As we will learn in Section 5.1, this will be also reflected in the distances to the frontier, since firms produced less in the crisis year while they were not able to adjust their capital stock and their use of labor in the short term. The former can only be adjusted through investment or the disposal of physical capital. Labor use also cannot be freely adjusted in Germany. Due to strong labor market regulation and collective labor agreements, long periods of notice prevent short-term adaption of the labor force. Figure 1 also suggest a strong relation between output and energy use.

Figure 1: Descriptive Statistics: Development across industries.
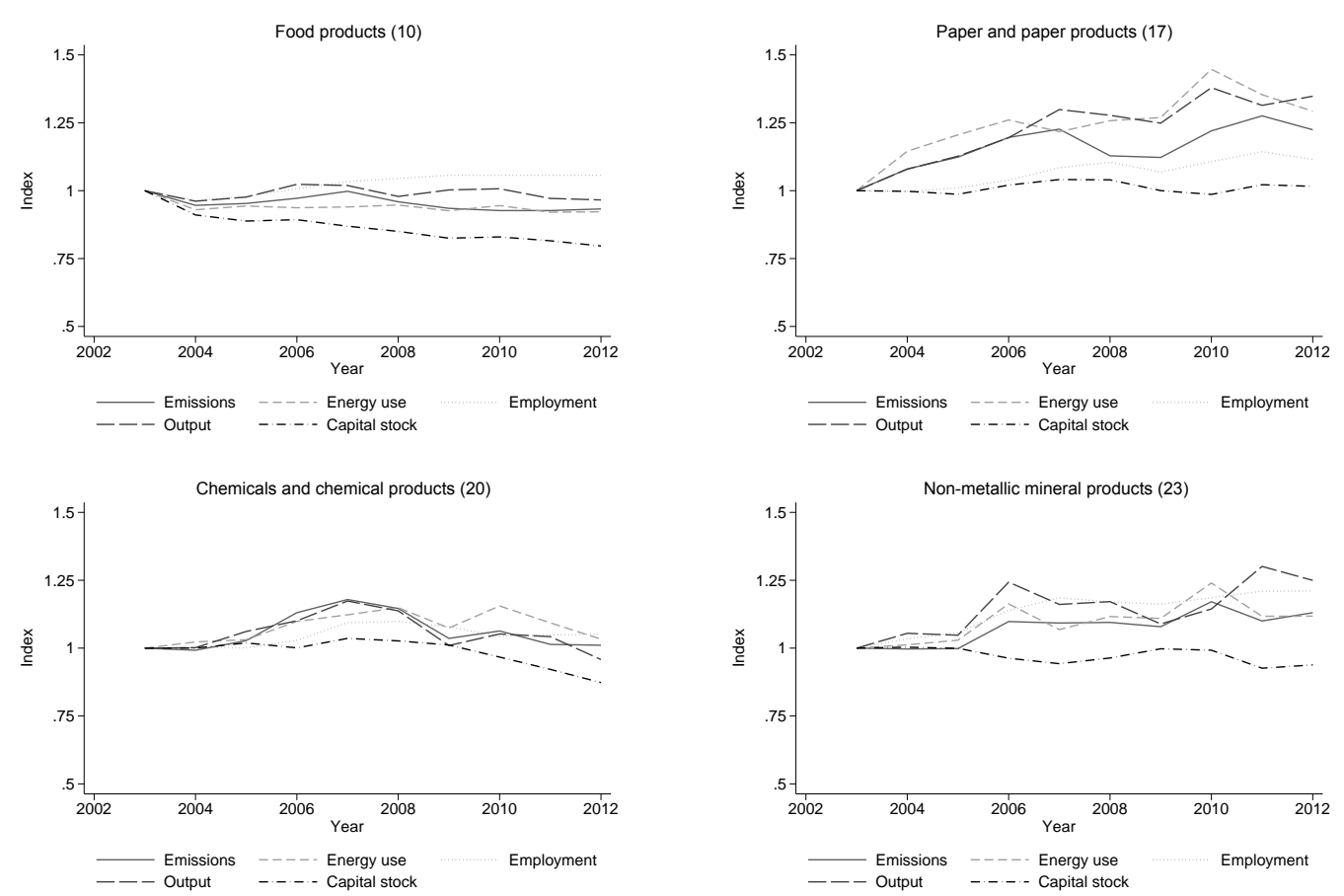

Notes: Indexed medians (base year 2003) for emissions, energy use, employment, output, and capital stock. Source: Research Data Centres of the Statistical Offices Germany (2014): Official Firm Data for Germany (AFiD) - AFiD-Panel Industrial Units and AFiD-Module Use of Energy, own calculations.

\footnotetext{
${ }^{13}$ Appendix B contains the graphs for each two-digit industry in manufacturing.
} 


\section{Results}

In this section, we present the parameter estimates of the stochastic production frontier model and shed light onto the development of efficiency across treatment and control group. We then empirically examine the core assumptions of our identification strategies and finally show the estimated treatment effects based on the different approaches.

\subsection{Stochastic production frontiers and efficiency}

The industries within the manufacturing sector differ considerably with respect to produced goods, production processes, and market structures. We take this heterogeneity into account and estimate separate Cobb-Douglas production frontiers for each two-digit industry providing a common point of reference for the entire time period from 2003 to 2012. Table 3 shows the parameter estimates of the stochastic production frontier model.

Table 3: Parameter estimates production frontier

\begin{tabular}{|c|c|c|c|c|c|c|c|c|}
\hline Industry (NACE) & \# Firms & Capital & Labor & Energy & Constant & $\hat{\sigma}_{u}$ & $\hat{\mu}_{\nu}$ & $\hat{\sigma}_{\nu}$ \\
\hline $\begin{array}{l}\text { Food products } \\
\text { (10) }\end{array}$ & 6935 & $\begin{array}{l}0.265 \\
(0.010)\end{array}$ & $\begin{array}{c}0.323 \\
(0.016)\end{array}$ & $\begin{array}{l}0.481 \\
(0.014)\end{array}$ & $\begin{array}{c}2.047 \\
(0.042)\end{array}$ & $\begin{array}{c}0.609 \\
(0.010)\end{array}$ & $\begin{array}{c}-443.728 \\
(6.786)\end{array}$ & $\begin{array}{l}11.969 \\
(0.384)\end{array}$ \\
\hline Beverages (11) & 703 & $\begin{array}{c}0.223 \\
(0.032)\end{array}$ & $\begin{array}{c}0.725 \\
(0.050)\end{array}$ & $\begin{array}{l}0.257 \\
(0.036)\end{array}$ & $\begin{array}{c}2.252 \\
(0.188)\end{array}$ & $\begin{array}{c}0.549 \\
(0.023)\end{array}$ & $\begin{array}{l}-365.726 \\
(119.853)\end{array}$ & $\begin{array}{c}9.839 \\
(2.725)\end{array}$ \\
\hline Textiles (13) & 1103 & $\begin{array}{c}0.199 \\
(0.020)\end{array}$ & $\begin{array}{c}0.738 \\
(0.037)\end{array}$ & $\begin{array}{l}0.117 \\
(0.016)\end{array}$ & $\begin{array}{l}3.652 \\
(0.104)\end{array}$ & $\begin{array}{c}0.507 \\
(0.019)\end{array}$ & $\begin{array}{l}-512.914 \\
(19.645)\end{array}$ & $\begin{array}{l}13.732 \\
(0.832)\end{array}$ \\
\hline $\begin{array}{l}\text { Leather and } \\
\text { related products } \\
\text { (15) }\end{array}$ & 231 & $\begin{array}{c}0.203 \\
(0.050)\end{array}$ & $\begin{array}{c}0.742 \\
(0.081)\end{array}$ & $\begin{array}{l}0.177 \\
(0.045)\end{array}$ & $\begin{array}{c}3.308 \\
(0.251)\end{array}$ & $\begin{array}{c}0.514 \\
(0.041)\end{array}$ & $\begin{array}{l}-908.894 \\
(27.054)\end{array}$ & $\begin{array}{l}24.299 \\
(1.631)\end{array}$ \\
\hline $\begin{array}{l}\text { Wood and pro- } \\
\text { ducts of wood } \\
\text { and cork }(16)\end{array}$ & 1587 & $\begin{array}{l}0.186 \\
(0.017)\end{array}$ & $\begin{array}{c}0.794 \\
(0.029)\end{array}$ & $\begin{array}{c}0.146 \\
(0.012)\end{array}$ & $\begin{array}{c}3.507 \\
(0.079)\end{array}$ & $\begin{array}{c}0.498 \\
(0.016)\end{array}$ & $\begin{array}{c}-513.569 \\
(16.601)\end{array}$ & $\begin{array}{l}13.775 \\
(0.552)\end{array}$ \\
\hline $\begin{array}{l}\text { Paper and } \\
\text { paper products } \\
(17)\end{array}$ & 1104 & $\begin{array}{c}0.178 \\
(0.021)\end{array}$ & $\begin{array}{c}0.677 \\
(0.031)\end{array}$ & $\begin{array}{l}0.183 \\
(0.012)\end{array}$ & $\begin{array}{c}3.720 \\
(0.089)\end{array}$ & $\begin{array}{c}0.389 \\
(0.017)\end{array}$ & $\begin{array}{l}-360.647 \\
(15.225)\end{array}$ & $\begin{array}{l}9.668 \\
(0.581)\end{array}$ \\
\hline $\begin{array}{l}\text { Printing and } \\
\text { reproduction of } \\
\text { recorded media } \\
\text { (18) }\end{array}$ & 2255 & $\begin{array}{c}0.115 \\
(0.013)\end{array}$ & $\begin{array}{c}0.689 \\
(0.026)\end{array}$ & $\begin{array}{l}0.250 \\
(0.014)\end{array}$ & $\begin{array}{c}3.580 \\
(0.061)\end{array}$ & $\begin{array}{c}0.367 \\
(0.011)\end{array}$ & $\begin{array}{l}-363.949 \\
(73.232)\end{array}$ & $\begin{array}{c}9.821 \\
(1.284)\end{array}$ \\
\hline $\begin{array}{l}\text { Chemicals and } \\
\text { chemical pro- } \\
\text { ducts }(20)\end{array}$ & 1722 & $\begin{array}{c}0.205 \\
(0.024)\end{array}$ & $\begin{array}{c}0.596 \\
(0.029)\end{array}$ & $\begin{array}{c}0.173 \\
(0.014)\end{array}$ & $\begin{array}{c}4.372 \\
(0.092)\end{array}$ & $\begin{array}{c}0.522 \\
(0.016)\end{array}$ & $\begin{array}{l}-607.081 \\
(40.582)\end{array}$ & $\begin{array}{l}16.373 \\
(0.883)\end{array}$ \\
\hline $\begin{array}{l}\text { Rubber and } \\
\text { plastic products } \\
(22)\end{array}$ & 3935 & $\begin{array}{c}0.155 \\
(0.011)\end{array}$ & $\begin{array}{l}0.726 \\
(0.017)\end{array}$ & $\begin{array}{l}0.178 \\
(0.010)\end{array}$ & $\begin{array}{c}3.645 \\
(0.047)\end{array}$ & $\begin{array}{c}0.416 \\
(0.008)\end{array}$ & $\begin{array}{l}-385.313 \\
(44.152)\end{array}$ & $\begin{array}{l}10.408 \\
(0.750)\end{array}$ \\
\hline $\begin{array}{l}\text { Other non- } \\
\text { metallic mineral } \\
\text { products }(23)\end{array}$ & 2446 & $\begin{array}{c}0.206 \\
(0.014)\end{array}$ & $\begin{array}{c}0.612 \\
(0.020)\end{array}$ & $\begin{array}{l}0.111 \\
(0.009)\end{array}$ & $\begin{array}{l}4.229 \\
(0.070)\end{array}$ & $\begin{array}{c}0.501 \\
(0.013)\end{array}$ & $\begin{array}{l}-471.085 \\
(5.073)\end{array}$ & $\begin{array}{l}12.644 \\
(0.427)\end{array}$ \\
\hline Basic metals (24) & 1274 & $\begin{array}{c}0.241 \\
(0.024)\end{array}$ & $\begin{array}{c}0.637 \\
(0.040)\end{array}$ & $\begin{array}{l}0.163 \\
(0.019)\end{array}$ & $\begin{array}{c}3.617 \\
(0.096)\end{array}$ & $\begin{array}{c}0.610 \\
(0.019)\end{array}$ & $\begin{array}{l}-300.333 \\
(11.398)\end{array}$ & $\begin{array}{l}8.107 \\
(0.761)\end{array}$ \\
\hline $\begin{array}{l}\text { Fabricated metal } \\
\text { products }(25)\end{array}$ & 9676 & $\begin{array}{c}0.103 \\
(0.006)\end{array}$ & $\begin{array}{c}0.896 \\
(0.011)\end{array}$ & $\begin{array}{l}0.112 \\
(0.006)\end{array}$ & $\begin{array}{c}3.791 \\
(0.030)\end{array}$ & $\begin{array}{c}0.458 \\
(0.006)\end{array}$ & $\begin{array}{c}-372.983 \\
(1.690)\end{array}$ & $\begin{array}{l}10.107 \\
(0.190)\end{array}$ \\
\hline $\begin{array}{l}\text { Electrical equip- } \\
\text { ment }(27)\end{array}$ & 3077 & $\begin{array}{c}0.170 \\
(0.011)\end{array}$ & $\begin{array}{c}0.834 \\
(0.021)\end{array}$ & $\begin{array}{l}0.071 \\
(0.011)\end{array}$ & $\begin{array}{l}4.088 \\
(0.049)\end{array}$ & $\begin{array}{c}0.449 \\
(0.010)\end{array}$ & $\begin{array}{c}-501.796 \\
(6.310)\end{array}$ & $\begin{array}{l}13.482 \\
(0.360)\end{array}$ \\
\hline $\begin{array}{l}\text { Machinery and } \\
\text { equipment n.e.c. } \\
(28)\end{array}$ & 8620 & $\begin{array}{c}0.071 \\
(0.006)\end{array}$ & $\begin{array}{l}1.066 \\
(0.011)\end{array}$ & $\begin{array}{l}0.027 \\
(0.007)\end{array}$ & $\begin{array}{c}4.092 \\
(0.032)\end{array}$ & $\begin{array}{c}0.453 \\
(0.006)\end{array}$ & $\begin{array}{l}-404.643 \\
(2.223)\end{array}$ & $\begin{array}{l}10.965 \\
(0.204)\end{array}$ \\
\hline $\begin{array}{l}\text { Motor vehicles, } \\
\text { trailers, and } \\
\text { semi-trailers (29) }\end{array}$ & 1681 & $\begin{array}{c}0.167 \\
(0.017)\end{array}$ & $\begin{array}{c}0.893 \\
(0.029)\end{array}$ & $\begin{array}{l}0.067 \\
(0.019)\end{array}$ & $\begin{array}{c}3.840 \\
(0.072)\end{array}$ & $\begin{array}{c}0.589 \\
(0.020)\end{array}$ & $\begin{array}{l}-405.271 \\
(53.125)\end{array}$ & $\begin{array}{l}10.924 \\
(1.072)\end{array}$ \\
\hline Furniture (31) & 1532 & $\begin{array}{c}0.133 \\
(0.013) \\
\end{array}$ & $\begin{array}{c}1.034 \\
(0.026) \\
\end{array}$ & $\begin{array}{l}0.036 \\
(0.016)\end{array}$ & $\begin{array}{c}3.599 \\
(0.071)\end{array}$ & $\begin{array}{c}0.433 \\
(0.014) \\
\end{array}$ & $\begin{array}{c}-409.503 \\
(7.892)\end{array}$ & $\begin{array}{l}11.030 \\
(0.481) \\
\end{array}$ \\
\hline
\end{tabular}

Notes: The number of observations includes all firms that were active during the period from 2003 to 2012 . We do not consider the industries manufacture of tobacco products (12), manufacture of wearing apparel (14), manufacture of pharmaceutical products (21), manufacture of computer, electronic and optical products (26), manufacture of other transport equipment (30), other manufacturing (32), and repair and installation of machinery and equipment (33). Source: Research Data Centres of the Statistical Offices Germany (2014): Official Firm Data for Germany (AFiD) - AFiD-Panel Industrial Units and AFiD-Module Use of Energy, own calculations.

The estimated parameters of the stochastic production frontier vary across industries 
reflecting the strong heterogeneity within the manufacturing sector. The economies of scale also vary across industries and range between 0.93 (manufacture of other nonmetallic mineral products; 23) and 1.20 (manufacture of beverages; 11). For the majority of industries, we observe statistically significant increasing economies of scale. Table 3 also shows the parameter estimates that characterize the distributions of the composite error term. The parameter $\hat{\sigma}_{u}$ denotes the estimated standard deviation of the mean zero normal distribution of the noise component $u_{i t}$. The parameters $\hat{\mu}_{\nu}$ and $\hat{\sigma}_{\nu}$ denote the estimated mean and standard deviation of the truncated normal distribution of the inefficiency component. The estimates for $\hat{\mu}_{\nu}$ are comparatively large, since we estimate a joint frontier for the entire time span from 2003 to 2012. This is necessary in order to obtain a single point of reference that allows for comparisons across years. As a robustness check, we also estimate the stochastic production frontiers using a value added representation. The results are similar to the results of the gross output representation and are reported in Appendix C.

Now we turn toward the development of efficiency over time and examine differences across treatment and control group. We focus on the four industries manufacture of food products (10), manufacture of paper and paper products (17), manufacture of chemicals and chemical products (20), and manufacture non-metallic mineral products (23). These industries contain a sufficiently high number of regulated firms and thus enable adequate statistical inference. ${ }^{14}$ Figure 2 consists of four graphs showing the development of the median distance to the production frontier over time within the four industries.

Since we estimate one stochastic frontier per industry that serves as reference point for the entire time period from 2003 to 2012, the dynamics of the distance to the production frontier reflect two developments. First, we observe that in all four industries, the median distance to the production frontier decreases during the early 2000s, i.e. the median firm becomes more efficient relative to the firms operating on the frontier. This trend in efficiency is driven by technological progress. We observe that the estimated stochastic frontier is determined by observations during the more recent years. Over time, the median distance to the production frontier decreases, since technological progress gradually pushes the firms toward the frontier. Secondly, we observe increases in the distance to the production frontier from 2006 onwards coinciding with the economic crisis. The distance to the production frontier peaks in 2009, the year when the crisis hit German manufacturing hardest. While demand and thus the production of goods rapidly decrease, firms do not adjust their capacity at the same speed. Therefore, low utilization rates increase the distance to the production frontier during the economic crisis (see Section 4 for details on input use). Our empirical strategy is not impaired by these developments as long as treatment and control group are equally affected conditional on observable firm characteristics and an array of fixed effects that depend on the estimated specification.

The distance to the production frontier of the median firm in the treatment group is

\footnotetext{
${ }^{14}$ For the subsample analysis, we only consider two-digit industries with at least 50 regulated firms.
} 
Figure 2: Comparison treatment and control group: median distance to the production frontier.
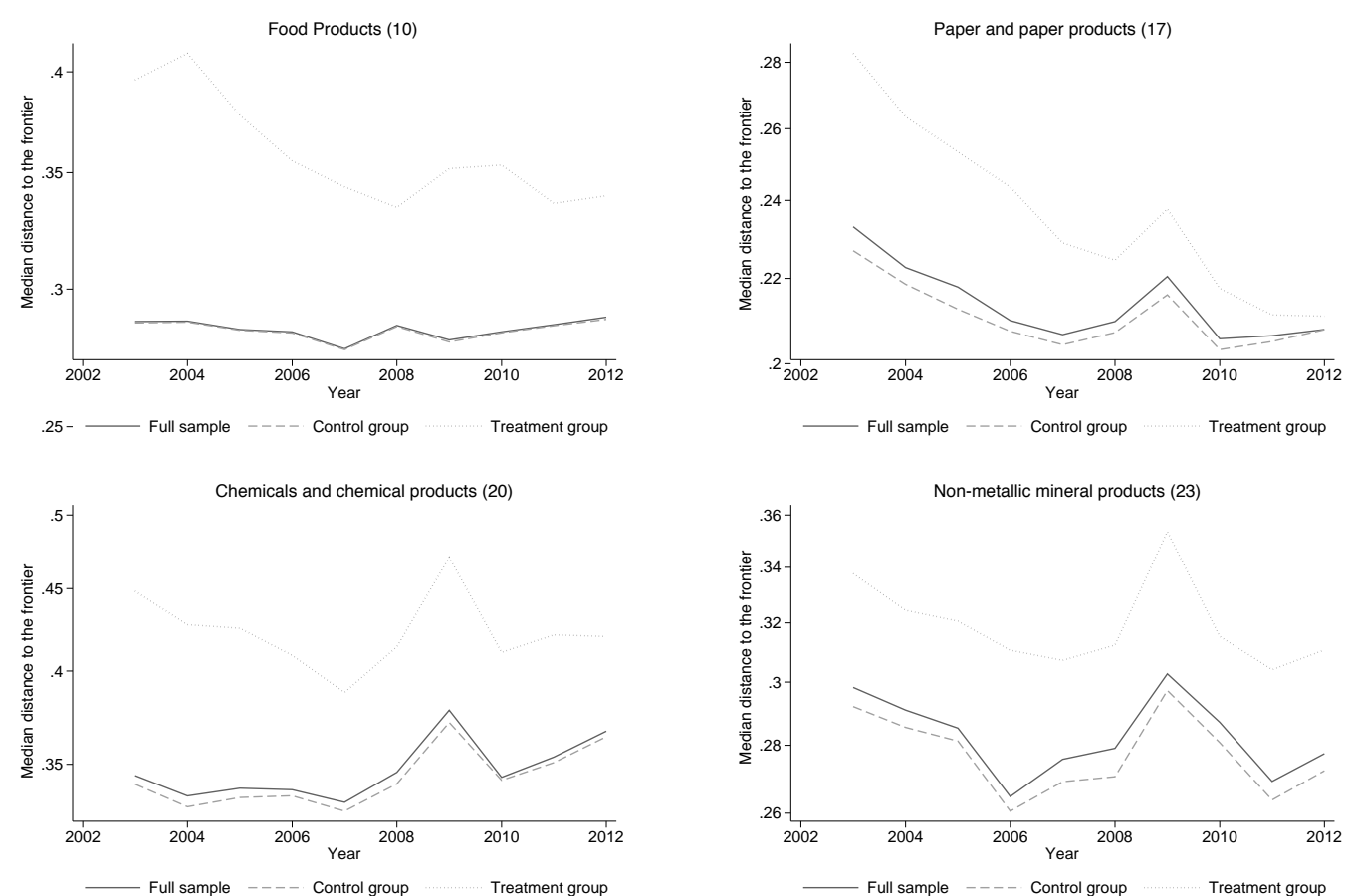

Notes: The vertical axis is displayed in log scale. Source: Research Data Centres of the Statistical Offices Germany (2014): Official Firm Data for Germany (AFiD) - AFiD-Panel Industrial Units and AFiD-Module Use of Energy, own calculations.

portrayed by the dotted line. It is higher than the distance to the production frontier of the median firm in the control group, indicating that the treated median firm operates less efficiently in these industries. The dashed line displays the development of the median distance the frontier among the firms of control group. It is close to the line of the overall median distance to the frontier reflecting that the share of control firms is high. For the industries manufacture of food products (10), manufacture of paper and paper products (17), and manufacture of chemicals and chemical products (20) the distance between the treatment and control group decreases over time. In particular during the years from 2005 to 2007, the distance to the production frontier of the median firm in the treatment group declines and thus converges toward the distance to the production frontier of the median firm in the control group. The industry manufacture of nonmetallic mineral products (23) does not show such a development.

\subsection{Empirical evidence on identifying assumptions}

In this section, we assess the validity of our key identifying assumptions that are described in Section 3 and derive strategies for our main analysis dealing with different potential problems.

Common support: We assume that for each firm, the conditional probability to be treated takes a positive, nonzero value smaller than one. This assumption can be examined by investigating the overlap of the distributions of the observable variables 
across treatment and control group. Table 4 shows descriptive statistics of the outcome variable distance to the frontier and the observable covariates for the pretreatment year 2003. The upper panel refers to the treated firms, i.e. the firms regulated by the EU ETS, whereas the lower panel refers to the control firms. A comparison of the percentiles across groups indicates, that the distributions of the distance to the frontier largely overlap across groups, i.e. that the common support assumption is reasonable for the outcome variable. The same comparison for the observable covariates reflects, however, the structural differences between treated and control firms. These differences occur due to the design of the EU ETS, that only regulates large emitters of $\mathrm{CO}_{2}$.

In order to check the robustness of our difference-in-differences approach with regard to the common support assumption, we estimate a specification that includes firm-level fixed effects. This specification primarily relies on the within variation and thus is less prone to violations of the common support assumption. In the framework of our nearest neighbor matching approach, we take this issue into account by only considering observations that fulfill the common support assumption, i.e. we drop observations outside the range of the overlap.

Table 4: Comparison of treated and control firms in 2003

\begin{tabular}{lcccccc}
\hline \hline & Mean & SD & P5 & P50 & P95 & N \\
\cline { 2 - 7 } ETS firms & & & & & \\
Distance to the frontier & 0.416 & 0.324 & 0.177 & 0.335 & 0.861 & 473 \\
Output (in 1000 EUR) & $502,169.00$ & $2,175,880.00$ & $2,967.29$ & $85,086.38$ & $1,598,206.00$ & 476 \\
Emissions (in t CO2) & $266,627.70$ & $845,970.20$ & $2,697.63$ & $53,453.96$ & $1,018,856.00$ & 475 \\
Capital stock (in 1,000 EUR) & $223,274.10$ & $785,493.00$ & $1,548.98$ & $40,658.98$ & $807,826.10$ & 477 \\
Number of employees & $1,844.19$ & $7,239.40$ & 28.83 & 352.33 & $7,512.33$ & 477 \\
Energy use (in MWh) & $859,570.40$ & $2,757,099.00$ & $8,246.018$ & $160,961.90$ & $3,231,146.00$ & 475 \\
& & & & & & \\
Non-ETS firms & & & & & & \\
Distance to the frontier & 0.342 & 0.322 & 0.145 & 0.272 & 0.725 & 35,122 \\
Output (in 1,000 EUR) & $22,675.17$ & $262,125.30$ & 912.28 & $5,187.19$ & $76,554.40$ & 37,412 \\
Emissions (in t CO2) & $3,970.36$ & $65,167.58$ & 39.81 & 363.49 & $9,820.83$ & 36,510 \\
Capital stock (in 1,000 EUR) & $8,561.55$ & $77,898.59$ & 144.87 & $1,797.59$ & $28,903.38$ & 36,622 \\
Number of employees & 131.75 & 998.39 & 19.50 & 49.50 & 421.25 & 37,842 \\
Energy Use (in MWh) & $10,503.44$ & $188,057.90$ & 93.48 & 887.83 & $25,274.52$ & 36,474 \\
\hline
\end{tabular}

Notes: Output (production value), and capital stock are denoted in 1000 EUR. Energy use is denoted in MWh and $\mathrm{CO}_{2}$ emissions in $\mathrm{CO}_{2}$. Source: Research Data Centres of the Statistical Offices Germany (2014): Official Firm Data for Germany (AFiD) - AFiD-Panel Industrial Units and AFiD-Module Use of Energy, own calculations.

Unconfoundedness: For our baseline difference-in-differences specification, we assume that the counterfactual distance to the production frontier is equally distributed across treatment and control group conditional on the group, industry, and year fixed effects as well as interaction terms. We relax this assumption gradually by including additional observable firm characteristics and then firm-level fixed effects. We are able to investigate the validity of this assumption by analyzing differences in pretreatment trends of the outcome variable across groups. In particular, we apply our identification strategies 
to the pretreatment years assuming that the EU ETS was already introduced in 2004. The upper panel in Table 5 shows the resulting placebo treatment effects for our baseline difference-in-differences specification (Specification A) and the difference-in-differences specification including observable firm characteristics as covariates (Specification B). While our assumption of parallel trends in the absence of treatment holds for our subsample analysis, we see that for the full sample of manufacturing, there might be differences across treatment and control group that are not captured by the fixed effects and the observational covariates. The placebo effect is economically small, but statistically significant. When interpreting the results of Specification B for the full sample, we have to take this into account. Furthermore, we add Specification $\mathrm{C}$ with firm level fixed effects to better control for unobserved differences across groups.

Table 5: Pretreatment analysis

\begin{tabular}{|c|c|c|c|}
\hline \multicolumn{4}{|c|}{ Parametric difference-in-differences model } \\
\hline & & Specification A & Specification B \\
\hline Manufacturing (full sample) & & $\begin{array}{l}-0.0186 \\
(0.0098)\end{array}$ & $\begin{array}{c}-0.0095^{*} \\
(0.0038)\end{array}$ \\
\hline Food products $(10)$ & & $\begin{array}{c}0.0034 \\
(0.0178)\end{array}$ & $\begin{array}{l}-0.0057 \\
(0.0072)\end{array}$ \\
\hline $\begin{array}{l}\text { Paper and paper } \\
\text { products (17) }\end{array}$ & & $\begin{array}{l}-0.0178 \\
(0.0275)\end{array}$ & $\begin{array}{l}-0.0058 \\
(0.0034)\end{array}$ \\
\hline $\begin{array}{l}\text { Chemicals and } \\
\text { chemical products }(20)\end{array}$ & & $\begin{array}{l}-0.0376 \\
(0.0259)\end{array}$ & $\begin{array}{l}-0.0032 \\
(0.0034)\end{array}$ \\
\hline $\begin{array}{l}\text { Other non-metallic } \\
\text { mineral products }(23)\end{array}$ & & $\begin{array}{l}-0.0090 \\
(0.0193)\end{array}$ & $\begin{array}{l}-0.0018 \\
(0.0031)\end{array}$ \\
\hline \multicolumn{4}{|c|}{ Nearest neighbor matching difference-in-differences } \\
\hline & one neighbor & five neighbors & twenty neighbors \\
\hline Manufacturing (full sample) & $\begin{array}{l}0.0168 \\
(0.0168)\end{array}$ & $\begin{array}{l}0.0010 \\
(0.0116)\end{array}$ & $\begin{array}{c}0.0012 \\
(0.0090)\end{array}$ \\
\hline
\end{tabular}

Notes: Standard errors are computed by using a block bootstrap procedure with 500 replications - robust with regard to heteroskedasticity and intra-firm correlation. * significant at the $5 \%$ level. A denotes the baseline specification, B includes explanatory variables. Source: Research Data Centres of the Statistical Offices Germany (2014): Official Firm Data for Germany (AFiD) - AFiD-Panel Industrial Units and AFiD-Module Use of Energy, own calculations.

The lower panel in Table 5 shows the placebo treatment effects based on our matching approach for different numbers of nearest neighbors chosen by the Mahalanobis distance. None of the estimates is statistically significant indicating that the conditional unconfoundedness assumption holds for the matching approach.

SUTVA: Our identification strategy relies on the assumption of stability of unit treatment values. It requires that the regulation by the EU ETS only affects regulated firms excluding spillover and equilibrium effects. This assumption cannot be directly tested. However, it is possible to estimate alternative specifications taking potential equilibrium effects into account. For our examination of the effects of the EU ETS, we 
differentiate between two cases: SUTVA could be either violated by equilibrium effects across or within industries.

For the first case, consider, for example, a situation, where the EU ETS creates incentives for regulated firms to invest in abatement technology or new, more efficient machinery. As a consequence, the EU ETS does not only affect treated firms, for example in the cement or glass industry, but also indirectly potential control firms in other industries, such as firms manufacturing machinery and equipment. A similar line of thought is applicable to unregulated firms in the coking and refining industries, if regulated firms switch from carbon intensive to less carbon intensive fuels or energy (e.g. renewable energy sources). We aim to overcome this violation of SUTVA by examining the effect of the EU ETS within subsamples, in particular two-digit industries.

For the second case, the SUTVA violation within industries, consider for example a situation, where production is shifted from regulated to unregulated facilities. Fowlie, Holland, and Mansur (2012) use spatial variation in stringency of regulation. For our application, this is regrettably not feasible, since the EU ETS is uniformly applied to the regulated firms. We will discuss potential consequences of this kind of SUTVA violation for our results in Section 6

\subsection{Difference-in-differences}

The estimated treatment effects based on our three parametric difference-in-differences specifications are reported in Table 6. Specification A, B, and C refer to the baseline specification described in Equation 3, the specification including explanatory variables described in Equation 4, and the specification including explanatory variables and firm-level fixed effects described in Equation 5, respectively. All specifications include two-digit industry fixed effects, year fixed effects and complete interaction terms. The distance to the production frontier is computed as difference between the output predicted by the stochastic production frontier and the actual output of the firm. This distance to the frontier is positive for all firms. We take the natural logarithm of outcome variable and explanatory variables, the estimated treatment effects thus can be interpreted as semi-elasticities.

The first row of Table 6 shows the results for the entire manufacturing sector. The estimated treatment effects of Specification A indicate an economically and statistically significant negative impact of the EU ETS on the distance to the production frontier. However, when we include additional observable explanatory variables (Specification B) and firm-level fixed effects (Specification C), then the effect diminishes and becomes statistically insignificant. These results suggest that the estimated treatment effects based on Specification A are biased due to confounding factors, which we are able to control for in the Specifications B and C.

Heterogeneity across industries within the manufacturing sector, for example with regard to abatement options and free allocation, might lead to insignificant treatment effects for the manufacturing sector as a whole. We therefore examine the estimated 
Table 6: Difference-in-differences treatment effects

\begin{tabular}{|c|c|c|c|c|c|c|}
\hline \multirow[b]{2}{*}{ Compliance period } & \multicolumn{2}{|c|}{ Specification A } & \multicolumn{2}{|c|}{ Specification B } & \multicolumn{2}{|c|}{ Specification $\mathrm{C}$} \\
\hline & $03-07$ & $03-12$ & $03-07$ & $03-12$ & $03-07$ & $03-12$ \\
\hline $\begin{array}{l}\text { Manufacturing } \\
\text { (full sample) }\end{array}$ & $\begin{array}{c}-0.0382^{*} \\
(0.0102)\end{array}$ & $\begin{array}{l}-0.0510^{*} \\
(0.0130)\end{array}$ & $\begin{array}{c}0.0003 \\
(0.0054)\end{array}$ & $\begin{array}{l}-0.0003 \\
(0.0066)\end{array}$ & $\begin{array}{l}-0.0052 \\
(0.0029)\end{array}$ & $\begin{array}{l}-0.0042 \\
(0.0039)\end{array}$ \\
\hline Food products (10) & $\begin{array}{l}-0.0284 \\
(0.0274)\end{array}$ & $\begin{array}{l}-0.0667 \\
(0.0353)\end{array}$ & $\begin{array}{l}-0.0058 \\
(0.0039)\end{array}$ & $\begin{array}{l}-0.0066 \\
(0.0057)\end{array}$ & $\begin{array}{l}-0.0036 \\
(0.0035)\end{array}$ & $\begin{array}{c}0.0003 \\
(0.0056)\end{array}$ \\
\hline $\begin{array}{l}\text { Paper and paper } \\
\text { products (17) }\end{array}$ & $\begin{array}{l}-0.0137 \\
(0.0252)\end{array}$ & $\begin{array}{l}-0.0872^{*} \\
(0.0299)\end{array}$ & $\begin{array}{l}-0.0139^{*} \\
(0.0038)\end{array}$ & $\begin{array}{l}-0.0210^{*} \\
(0.0047)\end{array}$ & $\begin{array}{c}-0.0134^{*} \\
(0.0039)\end{array}$ & $\begin{array}{r}-0.0167^{*} \\
(0.0044)\end{array}$ \\
\hline $\begin{array}{l}\text { Chemicals and } \\
\text { chemical products }(20)\end{array}$ & $\begin{array}{l}-0.0176 \\
(0.0309)\end{array}$ & $\begin{array}{l}-0.0440 \\
(0.0426)\end{array}$ & $\begin{array}{l}-0.0010 \\
(0.0049)\end{array}$ & $\begin{array}{l}0.0009 \\
(0.0057)\end{array}$ & $\begin{array}{l}-0.0074 \\
(0.0041)\end{array}$ & $\begin{array}{l}-0.0048 \\
(0.0056)\end{array}$ \\
\hline $\begin{array}{l}\text { Other non-metallic } \\
\text { mineral products }(23)\end{array}$ & $\begin{array}{c}0.0009 \\
(0.0161)\end{array}$ & $\begin{array}{l}-0.0185 \\
(0.0210)\end{array}$ & $\begin{array}{l}-0.0036 \\
(0.0025)\end{array}$ & $\begin{array}{l}-0.0045 \\
(0.0029)\end{array}$ & $\begin{array}{l}-0.0043 \\
(0.0024)\end{array}$ & $\begin{array}{l}-0.0040 \\
(0.0026) \\
\end{array}$ \\
\hline
\end{tabular}

Notes: Standard errors are computed by using a block bootstrap procedure with 500 replications. The standard errors are robust with regard to heteroskedasticity and intra-firm correlation. ${ }^{*}$ significant at the $5 \%$ level. A denotes the baseline specification, B includes explanatory variables, and C includes explanatory variables and firm-level fixed effects. All specifications include industry and time fixed effects and the full set of interaction terms. Source: Research Data Centres of the Statistical Offices Germany (2014): Official Firm Data for Germany (AFiD) - AFiD-Panel Industrial Units and AFiD-Module Use of Energy, own calculations.

treatment effects for two-digit industries with sufficient observations in the treatment group. For the industries manufacture of food products, chemicals and chemical products, and other non-metallic mineral products (cement, glass, etc.), we do not find a significant effect of the EU ETS on the distance to the production frontier. Similar to the results based on the entire manufacturing sample, the estimates diminish, when controlling for confounding factors.

For the paper industry, however, we find statistically and economically significant treatment effects for all specifications and time periods considered. The size of the estimated treatment effects also decreases when controlling for confounding factors. Our preferred difference-in-differences model is Specification C indicating a -1.34 percent decrease in the mean distance between regulated firms and the production frontier due to the EU ETS when considering only data until the end of Phase I and a -1.67 percent decrease when considering the data for both trading periods. In order to further investigate the better performance of EU ETS regulated firms in the paper industry, we show in Figure 3 the development of the indexed median of the output and inputs for treatment and control group separately. Figure 3 indicates, that the output of the treatment group increased more strongly in comparison to the control group during Phase I and Phase II. Furthermore, the treatment group conducted higher investments during the years 2007 and 2009 leading to a slightly higher capital stock during Phase II in comparison to the control group. The firms of the treatment group decreased employment after the investments in new capital stock. The energy use follows a similar trend across groups. This investigation of the descriptive statistics suggests that the difference in the distances to the production frontier across groups mostly evolved due to increased output and investments in capital that is more efficient with regard to the use of employment. 
Figure 3: Comparison treatment and control group - manufacture of paper and paper products.
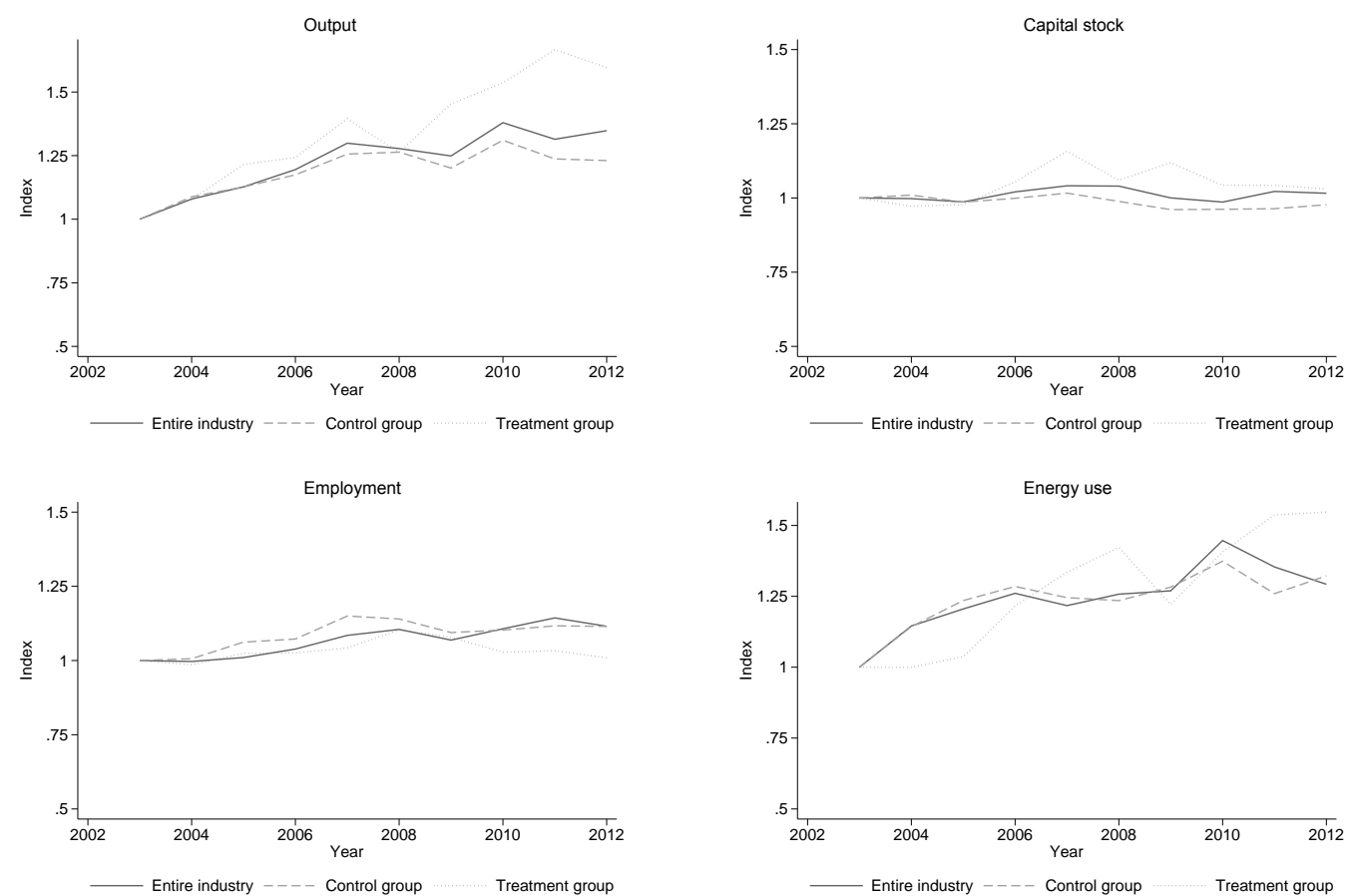

Notes: Source: Research Data Centres of the Statistical Offices Germany (2014): Official Firm Data for Germany (AFiD) - AFiD-Panel Industrial Units and AFiD-Module Use of Energy, own calculations.

\subsection{Nearest neighbor matching}

After the difference-in-difference approach with different conditioning strategies, we complement our analysis with a nearest neighbor matching approach. Table 7 shows the result of the different specifications. Following Fowlie, Holland, and Mansur (2012), we implement a combination of nearest neighbor matching and difference-in-differences. Instead of parametrically accounting for observable confounding factors, we identify an adequate control group using the Mahalanobis distance that determines similarity between firms by a weighted function of observable covariates for each firm. The weight is based on the inverse of the covariates' variance-covariance-matrix. This approach is nonparametric and does not assume a functional form for the outcome- or the treatmentmodel. The intuition behind this approach is to form a control group using unregulated firms that resemble the firms in the treatment group and thus might be affected by unobservable confounding factors in the same way. In line with Fowlie, Holland, and Mansur (2012), we apply nearest neighbor matching with replacement, i.e. unregulated firms can be used multiple times as a match.

We match on the firms' output, emissions, deployed capital stock, number of employees, and energy use in 2003 and match exactly on two-digit industries. ${ }^{15}$ Table 7 shows estimated treatment effects for matching with the nearest neighbor, the five nearest neighbors, and the 20 nearest neighbors, respectively. The results should be interpreted

\footnotetext{
${ }^{15}$ Two-digit industries without treated firms are not considered in the estimation.
} 
Table 7: Nearest neighbor matching treatment effects

\begin{tabular}{|c|c|c|c|}
\hline & one neighbor & five neighbors & twenty neighbors \\
\hline \multicolumn{4}{|c|}{ Year by year comparison (base year 2003) } \\
\hline \multirow[t]{2}{*}{2005} & -0.0158 & $-0.0343^{*}$ & $-0.0277^{*}$ \\
\hline & $(0.0149)$ & $(0.0134)$ & $(0.0120)$ \\
\hline \multirow[t]{2}{*}{2006} & -0.0169 & -0.0121 & -0.0087 \\
\hline & $(0.0153)$ & $(0.0133)$ & $(0.0134)$ \\
\hline \multirow[t]{2}{*}{2007} & -0.0152 & 0.0015 & -0.0080 \\
\hline & $(0.0224)$ & $(0.0167)$ & $(0.0154)$ \\
\hline \multirow[t]{2}{*}{2008} & -0.0171 & -0.0001 & 0.0013 \\
\hline & $(0.0247)$ & $(0.0172)$ & $(0.0288)$ \\
\hline \multirow[t]{2}{*}{2009} & 0.0013 & 0.0069 & -0.0018 \\
\hline & $(0.0288)$ & $(0.0222)$ & $(0.0193)$ \\
\hline \multirow[t]{2}{*}{2010} & -0.0226 & -0.0038 & -0.0066 \\
\hline & $(0.0293)$ & $(0.0228)$ & $(0.0200)$ \\
\hline \multirow[t]{2}{*}{2011} & -0.0021 & -0.0129 & -0.0082 \\
\hline & $(0.0318)$ & $(0.0295)$ & $(0.0202)$ \\
\hline \multirow[t]{2}{*}{2012} & 0.0190 & 0.0029 & 0.0122 \\
\hline & $(0.0316)$ & $(0.0334)$ & $(0.0215)$ \\
\hline \multicolumn{4}{|c|}{ Comparison trading periods with pretreatment period } \\
\hline \multirow[t]{2}{*}{ Phase I } & $-0.0289^{*}$ & $-0.0280^{*}$ & $-0.0265^{*}$ \\
\hline & $(0.0124)$ & $(0.0119)$ & $(0.0108)$ \\
\hline \multirow[t]{2}{*}{ Phase II } & -0.0294 & -0.0097 & -0.0164 \\
\hline & $(0.0222)$ & $(0.0181)$ & $(0.0166)$ \\
\hline
\end{tabular}

Notes: Standard errors are robust with regard to heteroskedasticity and intra-firm correlation. * significant at the 5\% level. Source: Research Data Centres of the Statistical Offices Germany (2014): Official Firm Data for Germany (AFiD) - AFiD-Panel Industrial Units and AFiD-Module Use of Energy, own calculations.

jointly, since a higher number of matched control firms improves the efficiency of the estimate, but at the same time introduces potential bias (Smith, 1997). The upper panel in Table 7 shows estimated treatment effects for year by year comparisons (base year is 2003). The lower panel shows estimated treatment effects for Phase I and Phase II. Apart from 2012, the estimated treatment effects are mostly negative. Only the year 2005 shows statistically significant effects that range between -2.77 and -3.43 percent. Pooling the data for the compliance periods, we find a significant negative effect of the EU ETS on firm specific distance to the production frontier during Phase I. The parameter estimates for the treatment effect in Phase II are of the same magnitude but statistically insignificant. 


\section{Concluding Discussion}

In this study, we investigate the effect of the EU ETS on the economic performance of regulated German manufacturing firms. We estimate a stochastic production frontier to recover the firm specific distance to the production frontier as a measure for economic performance. Combining the difference-in-differences framework with parametric conditioning strategies and nonparametric nearest neighbor matching, we isolate the effect of the EU ETS on the firm specific distance to the production frontier.

The results of the parametric difference-in-differences approach suggest that the EU ETS does not homogeneously affect firms in the manufacturing sector. We do not find a statistically significant effect of the EU ETS using data for the entire manufacturing sector. A subsample analysis on the two-digit industry level, however, shows that the EU ETS has a stronger influence on firms in particular industries. The industries manufacture of food products (10), manufacture of paper and paper products (17), manufacture of chemicals and chemical products (20), and manufacture of non-metallic mineral products (23) contain a sufficiently high number of regulated firms and enable us to examine the effect of the EU ETS on firms within narrowly defined industries. While we do not find a statistically significant effect of the EU ETS on the industries 10, 20, and 23, we find that the EU ETS significantly increased the economic performance of regulated firms in the paper industry.

The results based on the nonparametric nearest neighbor matching suggest a statistically significant positive effect of the EU ETS on the economic performance of the regulated firms during the Phase I of the EU ETS. A year-by-year analysis shows that the effect was only significant during the first year of Phase I. The EU ETS therefore had a particular strong effect when it was introduced.

Even though our analysis is different from Petrick and Wagner (2014) and Lutz (2016) with regard to the estimated measure of economic performance and with regard to the identification strategy, our results support their findings. Both studies do not find a statistically negative significant effect of the EU ETS on output, input use, and productivity. In contrast, Petrick and Wagner (2014) find a positive effect of the EU ETS on output while the inputs remain unaffected and Lutz (2016) finds a positive effect on productivity. Our analysis adds to the literature by characterizing economic performance relative to the most efficient firms. Furthermore, we provide a profound subsample analysis that helps to better understand the heterogeneity of the treatment effect of the EU ETS.

Although we cannot fully clarify the mechanisms at work, we conjecture that the EU ETS might have incentivized investments in more efficient capital stock that allowed the firms to produce more output with less inputs. Alternatively, firms might have profited from free allocation and might have used the free resources to invest in more efficient capital stock.

When interpreting the results of our empirical analysis, it is important to bear in mind that we assume the EU ETS only to influence the treated firms. However, through 
spillover and equilibrium, effects the EU ETS might also have an impact on the economic performance of untreated firms. Conducting a subsample analysis, we can take into account equilibrium effects across industries, but we are not able to control for equilibrium effects within industries.

Furthermore, the design of our empirical strategy focuses on the identification of the EU ETS. We do not consider other regulatory instruments, such as energy taxes, that might interact with the effects of the EU ETS.

In order to overcome these caveats, it would be necessary to choose a different empirical strategy with additional assumptions on the underlying economic structure. This endeavor is left for future research. In addition, it would be interesting to apply our empirical strategy to production census data from other countries in order to assess the generality of our results.

\section{Acknowledgements}

We thank Ulrich Wagner, Kathrine von Graevenitz, Katrin Sommerfeld, and Goytom Abraha Kahsay for suggestions and insightful comments. We thank the participants of the Münster Energy Conference 2016 as well as participants of the seminars at the University of Münster and at ZEW in Mannheim. We gratefully acknowledge the Research Data Centre (FDZ) of the Federal Statistical Office and the Statistical Offices of the German Länder for granting us access to the AFiD data and for the use of their research facilities, in particular Michael Rößner for his advice and technical support regarding the estimation of our empirical model. Andreas Löschel, Benjamin Johannes Lutz, and Shunsuke Managi thank the Helmholtz Association for the financial support through the Helmholtz Alliance ENERGY-TRANS. The views expressed in this paper are those of the authors and do not necessarily represent those of the ZEW or the FDZ.

\section{References}

AG Energiebilanzen E.V. (2014): "Energiebilanz der Bundesrepublik Deutschland 2003 - 2012," http://www.ag-energiebilanzen.de/7-0-Bilanzen-1990-2014.html, extracted on 29th of April, 2016.

Aigner, D., C. K. Lovell, and P. Schmidt (1977): "Formulation and estimation of stochastic frontier production function models," Journal of Econometrics, 6(1), 21-37.

Calel, R., and A. Dechezlepretre (2016): "Environmental policy and directed technological change: evidence from the European carbon market," Review of Economics and Statistics, (00).

Destatis (2015): "Deutscher Außenhandel: Export und Import im Zeichen der Globalisierung," https://www.destatis.de/DE/Publikationen/Thematisch/Aussenhandel/ 
Gesamtentwicklung/AussenhandelWelthandel5510006139004.pdf, extracted on 29th of April, 2016.

European Council (2014): "Conclusion EUCO 189/14 of the European Council of 23 nd 24 October 2004," Official Journal of the European Union, CO EUR 13.

European Parliament And Council (2003): "Directive 2003/87/EC of the European Parliament and of the Council of 13 October 2003 establishing a scheme for greenhouse gas emission allowance trading within the Community and amending Council Directive 96/61/EC," Official Journal of the European Union, L 275, 32-46.

(2004): "Directive 2004/101/EC of the European Parliament and of the Council of 27 October 2004 amending Directive 2003/87/EC establishing a scheme for greenhouse gas emission allowance trading within the Community, in respect of the Kyoto Protocol's project mechanisms," Official Journal of the European Union, L 338, 18-30.

(2009): "Directive 2009/29/EC of the European Parliament and of the Council of 23 April 2009 amending Directive 2003/87/EC so as to improve and extend the greenhouse gas emission allowance trading scheme of the Community," Official Journal of the European Union, L 140, 63-87.

Eurostat (2016): "Greenhouse gas emission statistics," http://ec.europa.eu/eurostat/statistics-explained/index.php/

Greenhouse_gas_emission_statistics, extracted on 29th of April, 2016.

Federal Environmental Agency (2008): "Bestimmung spezifischer TreibhausgasEmissionsfaktoren für Fernwärme," Federal Environmental Agency - Climate Change, 2008/08.

(2012): "Einheitliche Stoffwerte für Emissionsfaktoren, Heizwerte und Kohlenstoffgehalte für Brennstoffe, Rohstoffe und Produkte," https://www.dehst.de/SharedDocs/Downloads/Archiv/Zuteilung_2008-2012/

Anhang01_Stoffliste.html, extracted on 29th of April, 2016.

(2014): "Entwicklung der spezifischen Kohlendioxid-Emissionen des deutschen Strommix in den Jahren 1990 bis 2013," Federal Environmental Agency - Climate Change, 2014/23.

Fowlie, M., S. P. Holland, and E. T. Mansur (2012): "What Do Emissions Markets Deliver and to Whom? Evidence from Southern California's NOx Trading Program," American Economic Review, 102(2), 965-93.

Gray, W. B., R. J. Shadbegian, C. Wang, and M. Meral (2014): "Do EPA regulations affect labor demand? Evidence from the pulp and paper industry," Journal of Environmental Economics and Management, 68(1), 188-202. 
Heckman, J., H. Ichimura, J. Smith, and P. Todd (1998): "Characterizing selection bias using experimental data," Econometrica, 66(5), 1017-1098.

Heckman, J. J., H. Ichimura, and P. E. Todd (1997): "Matching as an econometric evaluation estimator: Evidence from evaluating a job training programme," The Review of Economic Studies, 64(4), 605-654.

Jaraité, J., And C. Di Maria (2016): "Did the EU ETS Make a Difference? An Empirical Assessment Using Lithuanian Firm-Level Data," The Energy Journal, 37(1), $1-23$.

Klemetsen, M. E., K. E. Rosendahl, and A. L. Jakobsen (2016): "The impacts of the EU ETS on Norwegian plants' environmental and economic performance," NMBU Working Papers 3/2016. Available at https://www.nmbu.no/sites/default/files/pdfattachments/hh_wp_3_2016_0.pdf.

Knittel, C. R. (2002): "Alternative Regulatory Methods and Firm Efficiency: Stochastic Frontier Evidence from the U.S. Electricity Industry," Review of Economics and Statistics, 84(3), 530-540.

Lutz, B. J. (2016): "Emissions Trading and Productivity: Firm-level Evidence from German Manufacturing," ZEW Discussion Paper No. 15-013.

Martin, R., M. MuÛls, and U. J. Wagner (in press): "The Impact of the EU ETS on Regulated Firms: What is the Evidence After Ten Years?," Review of Environmental Economics and Policy, -(-), -.

Meeusen, W., and J. Van den Broeck (1977): "Efficiency estimation from CobbDouglas production functions with composed error," International Economic Review, pp. $435-444$.

Petrick, S., K. Rehdanz, and U. J. Wagner (2011): "Energy use patterns in German industry: Evidence from-level data," Jahrbücher für Nationalökonomie und Statistik, pp. 379-414.

Petrick, S., And U. Wagner (2014): "The Impact of Carbon Trading on Industry: Evidence from German Manufacturing Firms," Available at SSRN: http://papers.ssrn.com/sol3/papers.cfm?abstract_id=2389800.

Research Data Centres of the Statistical Offices Germany (2014): “AFiDPanel Industrial Units, AFiD-Module Use of Energy, and Cost Structure Survey 19952010," Further information: http://www.forschungsdatenzentrum.de/en/index.asp.

Rubin, D. (1974): "Estimating causal effects of treatments in randomized and nonrandomized studies," Journal of Educational Psychology, 66, 688-701.

(1977): "Assignment to a treatment group on the basis of a covariate," Journal of Educational Statistics, 2, 1-26. 
Smith, H. L. (1997): "Matching With Multiple Controls to Estimate Treatment Effects in Observational Studies," Sociological Methodology, 27(1), 325-353.

Wagner, U. J., M. Mû̂Ls, R. Martin, and J. Colmer (2014): "The Causal Effects of the European Union Emissions Trading Scheme: Evidence from French Manufacturing Plants," Mimeo. 


\section{Appendix A. Data description}

Industry classification: The underlying industry classification NACE rev. 2 (Statistical Classification of Economic Activities in the European Community) is the European implementation of the UN classification ISIC rev. 4. From 2003 to 2008 the data set contains the industry classification based on NACE rev. 1.1. For these years, we use the four digit industry codes and the official reclassification guide of the statistical offices (Quelle) in order to transfer NACE rev. 1.1 code to NACE rev 2.

$\mathbf{C O}_{2}$ emissions: The Official Firm Data for Germany (Amtliche Firmendaten für Deutschland - AFiD) is a highly detailed data source with regard to energy use. The Energy Use Module contains information on the purchase, storage, sale, and use of 33 different fuels. We have access to slightly aggregated version of the Energy Use Module that contains information on 9 different fuels: natural gas, light fuel oil and heating oil, district heat, liquid gas, coal products, other mineral oil products, other gases, biomass, and other fuels. The Energy Use Module further includes information on the purchase, generation, sale, and use of electricity.

Following Petrick, Rehdanz, and Wagner (2011), we combine the energy use data from AFiD with data on $\mathrm{CO}_{2}$ content in fuels and electricity. Table 8 shows the emissions coefficients we use in order to compute plant and firm level $\mathrm{CO}_{2}$ emissions. The coefficients for natural gas, light fuel oil, and liquid gas are directly taken from the official statistics of the Federal Environmental Agency (2012). The Federal Environmental Agency (2008) computes $\mathrm{CO}_{2}$ emission coefficients for Germany in the years 2000 and 2005. We use the average coefficient over the two years. For the categories coal products, mineral oil products and other gases, we compute annual weighted averages in order to approximate adequate coefficients. The weights are determined by the sectoral use of the different fuels in the respective category and year (AG Energie Bilanz e.V., 2014). Our source for the electricity $\mathrm{CO}_{2}$ coefficients is the official report Federal Environmental Agency (2014).

Table 8: $\mathrm{CO}_{2}$ content electricity and fuel use

\begin{tabular}{|c|c|c|c|c|c|c|c|c|c|c|c|}
\hline & $03-12$ & 2003 & 2004 & 2005 & 2006 & 2007 & 2008 & 2009 & 2010 & 2011 & 2012 \\
\hline Natural gas & 201.6 & & & & & & & & & & \\
\hline Light fuel oil & 266.4 & & & & & & & & & & \\
\hline District heat & 219.5 & & & & & & & & & & \\
\hline Liquid gas & 230.4 & & & & & & & & & & \\
\hline Coal products & & 362.1 & 362.2 & 359.9 & 359.6 & 358.7 & 357.4 & 360.0 & 358.7 & 355.7 & 355.6 \\
\hline Mineral oil products & & 279.2 & 278.8 & 278.6 & 278.9 & 279.5 & 278.8 & 278.1 & 276.9 & 276.3 & 275.8 \\
\hline Other gases & & 195.9 & 195.9 & 195.9 & 195.9 & 195.8 & 195.9 & 195.9 & 195.8 & 195.5 & 195.6 \\
\hline Electricity & & 629 & 608 & 605 & 609 & 623 & 588 & 573 & 559 & 564 & 586 \\
\hline
\end{tabular}

Notes: Sources: Federal Environmental Agency (2008), Federal Environmental Agency (2012), Federal Environmental Agency (2014), and AG Energie Bilanz e.V. (2014), own calculations. 


\section{Appendix B. Descriptive statistics}

In Appendix B, we show additional descriptive statistics. Figure 4 sheds some light onto the development of the firm characteristics over time. Each plot shows indexed medians for the according two-digit industry. Figure 5 displays the price time series of the EUA futures traded at ICE.

Figure 4: Indexed medians for two-digit industries (I/II).
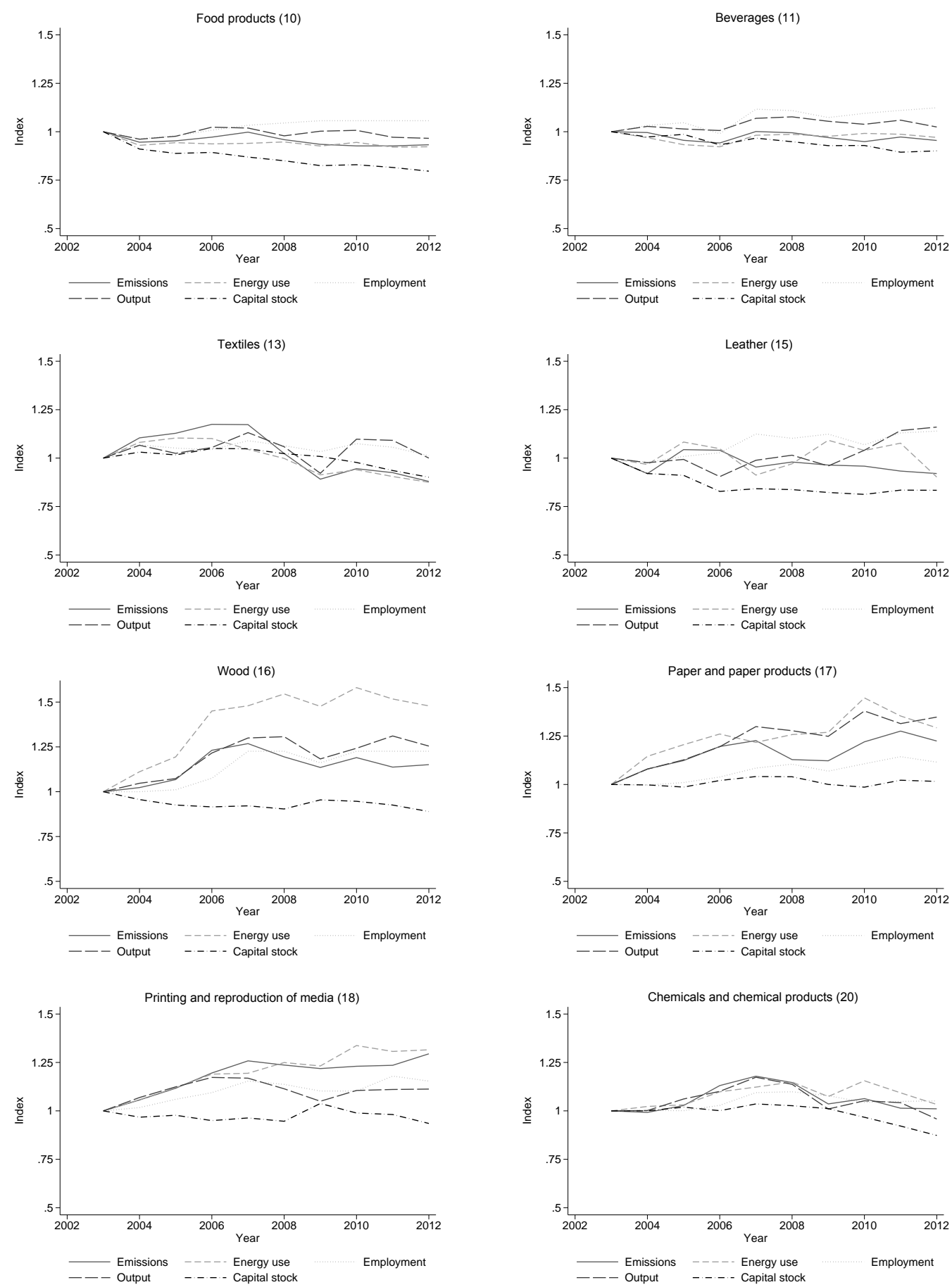

Notes: Source: Research Data Centres of the Statistical Offices Germany (2014): Official Firm Data for Germany (AFiD) - AFiD-Panel Industrial Units and AFiD-Module Use of Energy, own calculations. 
Indexed medians for two-digit industries (II/II).
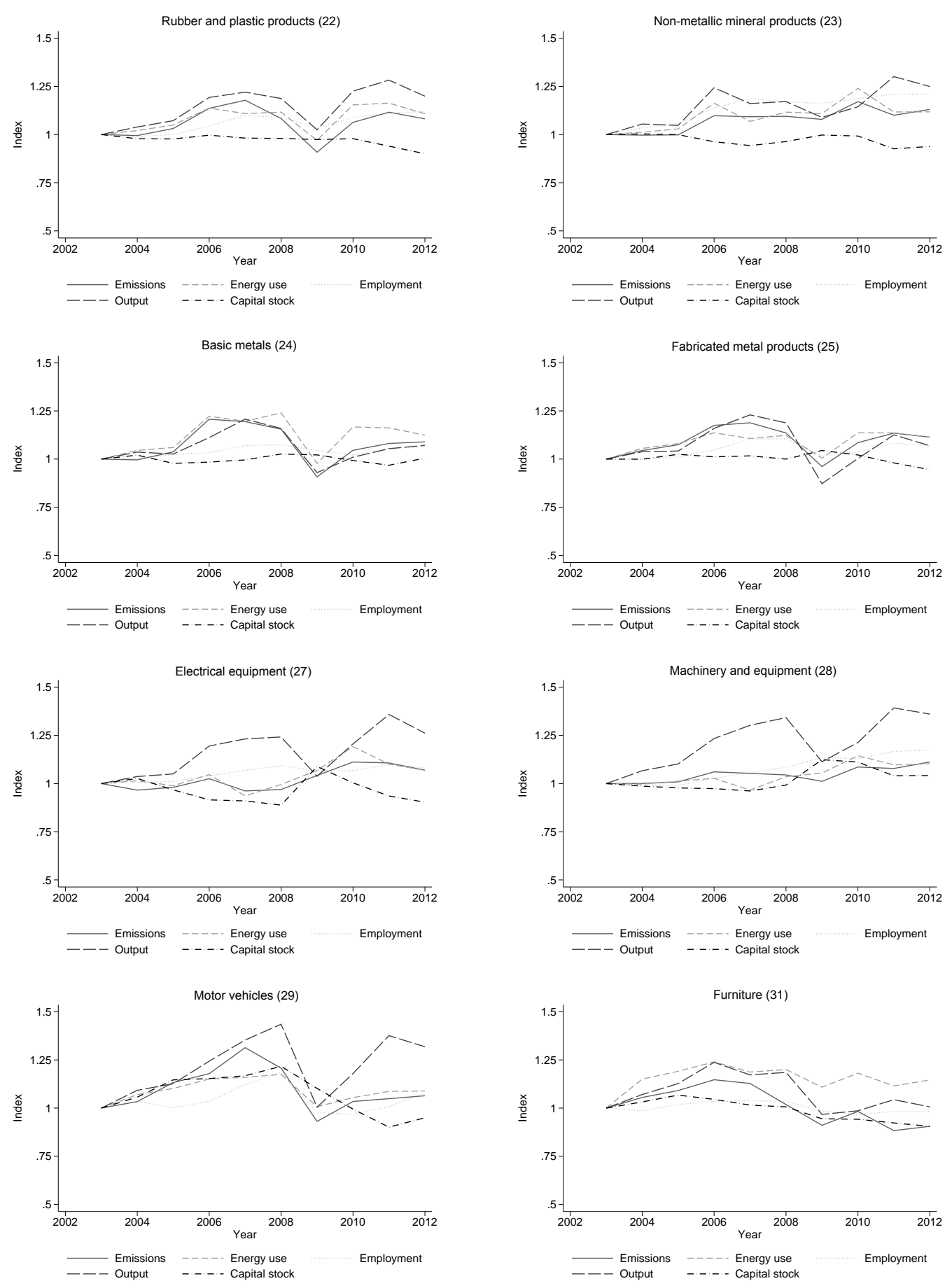

Notes: Source: Research Data Centres of the Statistical Offices Germany (2014): Official Firm Data for Germany (AFiD) - AFiD-Panel Industrial Units and AFiD-Module Use of Energy, own calculations. 
Figure 5: Price development - EUA futures.

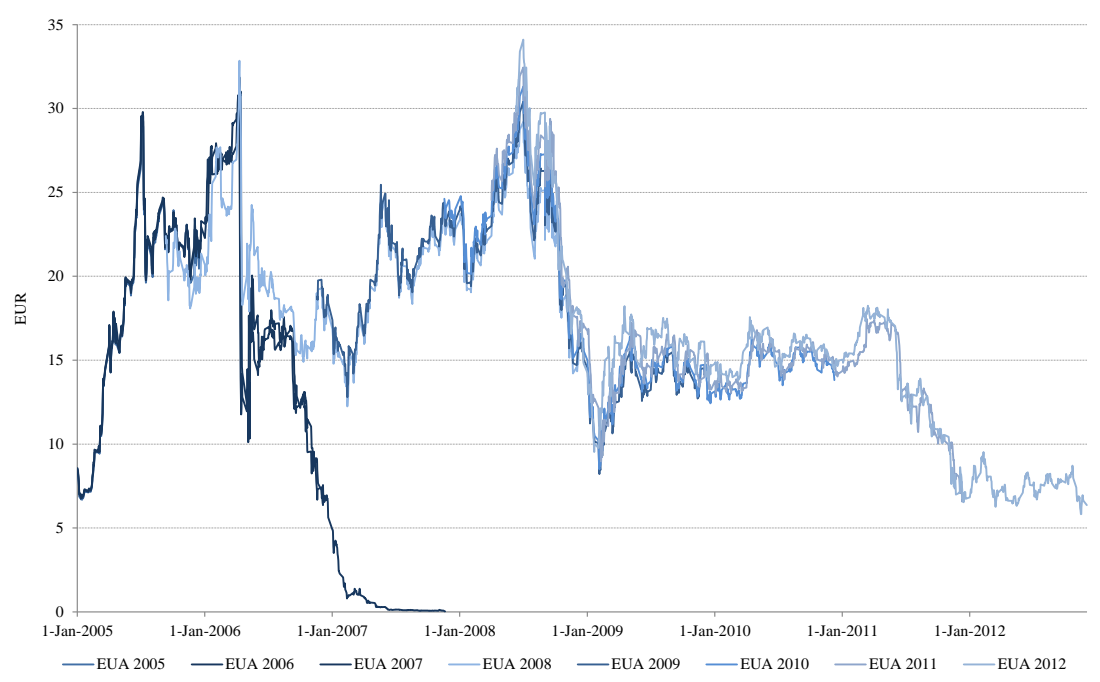

Notes: Source: ICE - accessed via Thomson Reuters Datastream. 


\section{Appendix C. Alternative approach: value added stochastic production frontier}

As a robustness check, we show results of an alternative stochastic production frontier. Instead of estimating a gross output production frontier, here, we estimate a value added production frontier. The estimation equation is the same as for the gross output production frontier. We only use value added as dependent variable instead of gross output. In addition, we show the results of the subsequent difference-in-differences analysis.

Table 9: Stochastic frontier results - value added specification

\begin{tabular}{|c|c|c|c|c|c|c|c|c|}
\hline NACE & Industry & \# Firms & Capital & Labor & Constant & $\sigma_{u}$ & $\mu_{\nu}$ & $\sigma_{\nu}$ \\
\hline 10 & Food products & 3687 & $\begin{array}{c}0.313 \\
(0.010)\end{array}$ & $\begin{array}{l}0.661 \\
(0.016)\end{array}$ & $\begin{array}{c}3.052 \\
(0.051)\end{array}$ & $\begin{array}{l}0.513 \\
(0.013)\end{array}$ & $\begin{array}{c}-338.702 \\
(4.423)\end{array}$ & $\begin{array}{c}9.163 \\
(0.315)\end{array}$ \\
\hline 11 & Beverages & 536 & $\begin{array}{c}0.162 \\
(0.039)\end{array}$ & $\begin{array}{c}0.936 \\
(0.058)\end{array}$ & $\begin{array}{l}3.255 \\
(0.209)\end{array}$ & $\begin{array}{l}0.715 \\
(0.050)\end{array}$ & $\begin{array}{l}-3.463 \\
(0.120)\end{array}$ & $\begin{array}{c}0.093 \\
(0.003)\end{array}$ \\
\hline 13 & Textiles & 905 & $\begin{array}{c}0.171 \\
(0.019)\end{array}$ & $\begin{array}{c}0.903 \\
(0.029)\end{array}$ & $\begin{array}{c}3.067 \\
(0.088)\end{array}$ & $\begin{array}{l}0.366 \\
(0.018)\end{array}$ & $\begin{array}{l}-388.038 \\
(81.580)\end{array}$ & $\begin{array}{l}10.431 \\
(1.388)\end{array}$ \\
\hline 15 & $\begin{array}{l}\text { Leather and } \\
\text { related products }\end{array}$ & 205 & $\begin{array}{c}0.241 \\
(0.032)\end{array}$ & $\begin{array}{c}0.851 \\
(0.055)\end{array}$ & $\begin{array}{c}2.704 \\
(0.145)\end{array}$ & $\begin{array}{c}0.417 \\
(0.037)\end{array}$ & $\begin{array}{l}-229.526 \\
(13.599)\end{array}$ & $\begin{array}{c}6.167 \\
(1.001)\end{array}$ \\
\hline 16 & $\begin{array}{l}\text { Wood and pro- } \\
\text { ducts of wood } \\
\text { and cork }\end{array}$ & 987 & $\begin{array}{c}0.164 \\
(0.016)\end{array}$ & $\begin{array}{c}0.894 \\
(0.024)\end{array}$ & $\begin{array}{c}3.263 \\
(0.063)\end{array}$ & $\begin{array}{c}0.341 \\
(0.013)\end{array}$ & $\begin{array}{c}-367.242 \\
(8.899)\end{array}$ & $\begin{array}{c}9.846 \\
(0.397)\end{array}$ \\
\hline 17 & $\begin{array}{l}\text { Paper and } \\
\text { paper products }\end{array}$ & 878 & $\begin{array}{c}0.223 \\
(0.018)\end{array}$ & $\begin{array}{c}0.844 \\
(0.029)\end{array}$ & $\begin{array}{c}3.061 \\
(0.075)\end{array}$ & $\begin{array}{c}0.338 \\
(0.015)\end{array}$ & $\begin{array}{l}-352.371 \\
(13.586)\end{array}$ & $\begin{array}{c}9.547 \\
(0.566)\end{array}$ \\
\hline 18 & $\begin{array}{l}\text { Printing and } \\
\text { reproduction of } \\
\text { recorded media }\end{array}$ & 978 & $\begin{array}{c}0.112 \\
(0.021)\end{array}$ & $\begin{array}{c}0.947 \\
(0.035)\end{array}$ & $\begin{array}{c}3.441 \\
(0.084)\end{array}$ & $\begin{array}{c}0.401 \\
(0.034)\end{array}$ & $\begin{array}{c}-266.503 \\
(5.343)\end{array}$ & $\begin{array}{c}7.135 \\
(0.825)\end{array}$ \\
\hline 20 & $\begin{array}{l}\text { Chemicals and } \\
\text { chemical pro- } \\
\text { ducts }\end{array}$ & 1494 & $\begin{array}{c}0.259 \\
(0.024)\end{array}$ & $\begin{array}{c}0.802 \\
(0.032)\end{array}$ & $\begin{array}{c}3.320 \\
(0.087)\end{array}$ & $\begin{array}{c}0.444 \\
(0.015)\end{array}$ & $\begin{array}{l}-401.639 \\
(10.496)\end{array}$ & $\begin{array}{l}10.788 \\
(0.410)\end{array}$ \\
\hline 22 & $\begin{array}{l}\text { Rubber and } \\
\text { plastic products }\end{array}$ & 2228 & $\begin{array}{c}0.187 \\
(0.012)\end{array}$ & $\begin{array}{c}0.876 \\
(0.016)\end{array}$ & $\begin{array}{c}3.143 \\
(0.050)\end{array}$ & $\begin{array}{c}0.339 \\
(0.009)\end{array}$ & $\begin{array}{l}-284.896 \\
(13.465)\end{array}$ & $\begin{array}{c}7.695 \\
(0.379)\end{array}$ \\
\hline 23 & $\begin{array}{l}\text { Other non- } \\
\text { metallic mineral } \\
\text { products }\end{array}$ & 1601 & $\begin{array}{c}0.237 \\
(0.011)\end{array}$ & $\begin{array}{c}0.795 \\
(0.016)\end{array}$ & $\begin{array}{c}3.239 \\
(0.060)\end{array}$ & $\begin{array}{c}0.361 \\
(0.012)\end{array}$ & $\begin{array}{l}-388.428 \\
(15.707)\end{array}$ & $\begin{array}{l}10.507 \\
(0.486)\end{array}$ \\
\hline 24 & Basic metals & 1098 & $\begin{array}{c}0.187 \\
(0.018)\end{array}$ & $\begin{array}{c}0.865 \\
(0.025)\end{array}$ & $\begin{array}{c}3.488 \\
(0.066)\end{array}$ & $\begin{array}{l}0.370 \\
(0.011)\end{array}$ & $\begin{array}{c}-386.221 \\
(8.959)\end{array}$ & $\begin{array}{l}10.393 \\
(0.368)\end{array}$ \\
\hline 25 & $\begin{array}{l}\text { Fabricated metal } \\
\text { products }\end{array}$ & 4934 & $\begin{array}{c}0.125 \\
(0.007)\end{array}$ & $\begin{array}{c}0.958 \\
(0.010)\end{array}$ & $\begin{array}{c}3.340 \\
(0.031)\end{array}$ & $\begin{array}{c}0.352 \\
(0.007)\end{array}$ & $\begin{array}{l}-264.760 \\
(18.406)\end{array}$ & $\begin{array}{c}7.150 \\
(0.388)\end{array}$ \\
\hline 27 & Electrical equipment & 2294 & $\begin{array}{l}0.162 \\
(0.016\end{array}$ & $\begin{array}{c}0.903 \\
(0.023)\end{array}$ & $\begin{array}{c}3.388 \\
(0.047)\end{array}$ & $\begin{array}{l}0.379 \\
(0.019)\end{array}$ & $\begin{array}{c}-318.548 \\
(7.684)\end{array}$ & $\begin{array}{c}8.576 \\
(0.405)\end{array}$ \\
\hline 28 & $\begin{array}{l}\text { Machinery and } \\
\text { equipment n.e.c. }\end{array}$ & 5821 & $\begin{array}{c}0.083 \\
(0.006)\end{array}$ & $\begin{array}{c}1.009 \\
(0.009)\end{array}$ & $\begin{array}{c}3.614 \\
(0.027)\end{array}$ & $\begin{array}{c}0.353 \\
(0.007)\end{array}$ & $\begin{array}{c}-317.811 \\
(4.628)\end{array}$ & $\begin{array}{c}8.588 \\
(0.204)\end{array}$ \\
\hline 29 & $\begin{array}{l}\text { Motor vehicles, } \\
\text { trailers, and } \\
\text { semi-trailers }\end{array}$ & 1401 & $\begin{array}{c}0.157 \\
(0.015)\end{array}$ & $\begin{array}{c}0.908 \\
(0.021)\end{array}$ & $\begin{array}{c}3.374 \\
(0.052)\end{array}$ & $\begin{array}{c}0.439 \\
(0.021)\end{array}$ & $\begin{array}{c}-335.859 \\
(4.972)\end{array}$ & $\begin{array}{c}9.031 \\
(0.377)\end{array}$ \\
\hline 31 & Furniture & 940 & $\begin{array}{c}0.140 \\
(0.014) \\
\end{array}$ & $\begin{array}{c}0.943 \\
(0.020) \\
\end{array}$ & $\begin{array}{r}3.2079 \\
(0.064) \\
\end{array}$ & $\begin{array}{c}0.328 \\
(0.018) \\
\end{array}$ & $\begin{array}{c}-304.466 \\
(6.713) \\
\end{array}$ & $\begin{array}{r}8.198 \\
(0.436) \\
\end{array}$ \\
\hline
\end{tabular}

Notes: Number of firms for the first year of Phase I of the EU ETS (2005), the first year of Phase II (2008) and the last year of Phase II (2012) that is also the last year we observe. Source: Research Data Centres of the Statistical Offices Germany (2014): Official Firm Data for Germany (AFiD) - AFiD-Panel Industrial Units and AFiD-Module Use of Energy, own calculations. 
Table 10: Pretreatment difference in differences

\begin{tabular}{lcc}
\hline \hline & Specification A & Specification B \\
\hline Manufacturing & -0.0186 & $-0.0095^{*}$ \\
& $(0.0098)$ & $(0.0038)$ \\
Food products (10) & 0.0034 & -0.0057 \\
& $(0.0178)$ & $(0.0072)$ \\
Paper and & -0.0178 & -0.0058 \\
paper pro- & $(0.0275)$ & $(0.0034)$ \\
ducts (17) & & \\
$\begin{array}{l}\text { Chemicals and } \\
\text { chemical pro- }\end{array}$ & -0.0376 & -0.0032 \\
ducts (20) & $(0.0259)$ & $(0.0034)$ \\
$\begin{array}{l}\text { Other non- } \\
\text { metallic mineral }\end{array}$ & -0.0090 & -0.0018 \\
products (23) & $(0.0193)$ & $(0.0031)$ \\
\hline \hline
\end{tabular}

Notes: Standard errors are computed by using a block bootstrap procedure with 500 replications - robust with regard to heteroskedasticity and intra-firm correlation. * significant at the 5\% level. Source: Research Data Centres of the Statistical Offices Germany (2014): Official Firm Data for Germany (AFiD) - AFiD-Panel Industrial Units and AFiD-Module Use of Energy, own calculations.

Table 11: Value added specification - treatment effects

\begin{tabular}{lccc}
\hline \hline & 2004 & $2005-2007$ & $2005-2012$ \\
\hline Specification A & $-0.0471^{*}$ & $-0.0464^{*}$ & -0.0048 \\
& $(0.0206)$ & $(0.0155)$ & $(0.0194)$ \\
Specification B & $-0.0429^{*}$ & $-0.0306^{*}$ & 0.0099 \\
& $(0.0191)$ & $(0.0151)$ & $(0.0171)$ \\
Specification C & - & $-0.0334^{*}$ & $-0.0528^{*}$ \\
& & $(0.0155)$ & $(0.0145)$ \\
\hline
\end{tabular}

Notes: Standard errors are computed by using a block bootstrap procedure with 500 replications - robust with regard to heteroskedasticity and intra-firm correlation. * significant at the $5 \%$ level. A denotes the baseline specification, B includes explanatory variables, $\mathrm{C}$ includes firm-level fixed effects. All specifications include industry and time fixed effects and the full set of interaction terms. ${ }^{*}$ significant at the $5 \%$ level. Source: Research Data Centres of the Statistical Offices Germany (2014): Official Firm Data for Germany (AFiD) - AFiD-Panel Industrial Units and AFiD-Module Use of Energy, own calculations. 